\title{
An alternative view of the peopling of South America: Lagoa Santa in craniometric perspective
}

\author{
Noriko SeGUCHI ${ }^{1 *}$, Ashley McKeOwN ${ }^{1}$, Ryan SCHMIdT ${ }^{1}$, Hideyuki UMEdA ${ }^{2}$, C. Loring BRACE ${ }^{3}$ \\ ${ }^{1}$ Department of Anthropology, University of Montana, Missoula, MT 59812, USA \\ ${ }^{2}$ Department of Astronomy, Faculty of Science, The University of Tokyo, Tokyo 113-0033, Japan \\ ${ }^{3}$ Museum of Anthropology, University of Michigan, Ann Arbor, MI 48109, MI USA
}

Received 21 September 2009; accepted 11 May 2010

\begin{abstract}
In this study, we compare the craniofacial morphology of four Sumidouro skulls and one Lund skull of paleo South Americans from Lagoa Santa, Brazil, with worldwide prehistoric and recent human craniofacial metric data, and suggest an alternative view of the migration history of early South America. Affiliations of samples and individuals were examined by the principal coordinate plot generated by Relethford and Blangero's R-matrix method, the neighbor-joining method based on genetic distance generated from the same R-matrix, and Mahalanobis distances and typicality probabilities. For these analyses, we examined certain variables claimed to have been influenced by the environment, such as maximum cranial length and maximum cranial breadth. Although the number of craniometric variables seems to influence the results of the analysis, it appeared to not obscure the ancestral and descendant relationships and regional kin relationships greatly in the instance of this study. Using Howells' worldwide comparative dataset but without the Jōmon sample, previous research had suggested that Brazilian Paleoamericans, the Lagoa Santa, were probably closely related to Australian Aborigines and Africans as opposed to Native Americans and Northeast Asians. On the other hand, using multivariate statistics, our results show that Lagoa Santa individuals exhibit stronger morphological affinities with the prehistoric Jōmon of Japan, archaic Americans of Indian Knoll Kentucky, Windover Florida, and Tennessee, and recent Tierra del Fuegans of South America, than with the Melanesians and Australians. Moreover, Jōmon, Lagoa Santa, and archaic North Americans all display close relationships and ties to each other. This suggests that the early inhabitants of South America were probably not related to Australo-Melanesians, but rather to the Late Pleistocene descendants of Northeast Asians such as the Jōmon. Also, they are related to the archaic North American populations and recent Central and South Americans.
\end{abstract}

Key words: craniometrics, Paleoamericans, the prehistoric Jōmon of Japan, archaic Americans

\section{Introduction}

Archaeological evidence suggests that human populations began to move into the New World from across Beringia beginning some time after 17000 years ago (Goebel, 1999). Those people were descendants of samples that had probably been in place for a long period of time prior to their move into the New World. Recently, biological anthropologists have turned their attention toward an assessment of the affinities of some of the older New World skeletal material in an effort to find out who these first intercontinental migrants may have been. The results of these studies are intriguing. The early inhabitants in the Americas have been suggested as resembling population samples ranging from Melanesia and Australia (with a South Asian connection), to Africa and Norway (Verneau, 1903, 1924; Rivet, 1908, 1957; Neves

\footnotetext{
* Correspondence to: Noriko Seguchi, Department of Anthropology, University of Montana, Missoula, MT 59812-1001, USA E-mail: noriko.seguchi@umontana.edu

Published online 24 July 2010

in J-STAGE (www.jstage.jst.go.jp) DOI: 10.1537/ase.090921
}

and Pucciarelli, 1991; Lahr, 1995; Neves et al., 1998, 2003, 2005; Powell and Neves, 1999; Brace et al., 2001, 2008; Jantz and Owsley, 2001; González-José et al., 2005; Neves and Hubbe, 2005).

In particular, Neves et al. $(1998,1999)$ have claimed that Paleoamericans of South America, with 'Luzia' as an example, represent a cranial morphology similar to that of Australian Aborigines and Sub-Saharan Africans. Neves and his colleagues (Neves et al., 1998, 1999, 2003, 2005; Neves and Hubbe, 2005) emphasize the traits that the earliest South Americans exhibit: narrow and long neurocrania; prognathic, low faces; and relatively low and broad orbits and nose. According to Neves and his colleagues, these traits tend to be more similar to present Australians, Melanesians, and Sub-Saharan Africans, while the recent Native Americans tend to exhibit a cranial morphology of short and wide neurocrania; high, orthognathic and broad faces; and relatively high and narrow orbits and noses similar to late and modern Northern Asians. Although researchers agree with the view that the immediate pre-Columbian residents and recent Native Americans are different from the Paleoamericans, all of them do not agree with the claim (Verneau, 1903; Rivet, 
1908, 1957; Neves and Pucciarelli, 1991; Neves et al., 2003; Neves and Hubbe, 2005) that Africans and Australians played an important role in acting as a source for the Paleoamericans. Apparently the craniofacial attributes of Old World and New World populations show some similarities; however, the early populations and some indigenous populations in Americas also fail to show close similarity to modern core Asian samples, such as Chinese.

The term 'Paleoindian' is used by many authors to refer to populations of the late Pleistocene and early Holocene (12000-8500 years BP) in the Americas thought to be associated with the Clovis, Folsom, and Cody archaeological complexes (Powell and Neves, 1999). Nearly all are contemporary with terminal Paleoindian and early archaic archaeological assemblages (Steele and Powell, 1992; Powell and Neves, 1999). Other researchers referring to the late Pleistocene and early Holocene populations in the New World use terms such as 'First Americans' or 'Paleoamericans' (Steele and Powell, 1999) to avoid implying that these early populations were ancestral to modern Native American populations. We follow these authors and refer to the Brazilian sample and other early populations in Americas as 'Paleoamerican' to avoid confusion. The term 'archaic' is used here to refer to populations of the middle and late Holocene (8500-3000 years BP). We use the term 'Native Americans' here to denote all indigenous peoples of the Americas.

Discussing the ancestral stock of the early entrants to the New World and the related issue of the origins of East Asians, some have argued that the morphological discontinuity between Upper Cave 101, Liujiang, Minatogawa, and Asians dating back to before the Neolithic period in China represent serious problems in proving continuity in the region (Kamminga and Wright, 1988; Wolpoff, 1994, 1995; Wright, 1995; Brown, 1999; Neves et al., 2003). Consequently, various studies suggest that the 29000-year-old Zhoukoudian Upper Cave 101 specimen is unlikely to be an ancestor of recent East Asians and suggest that Neolithic expansion in Asia replaced the Upper Cave 101 skull form with that of the recent Chinese form (Kamminga and Wright, 1988; Van Vark and Dijikema, 1988).

Again, some researchers have suggested the Upper Cave individuals in China are similar to Australians (Kamminga and Wright, 1988). Others argue that the Upper Cave 101 and Liujiang resemble the prehistoric Jomon of Japan and their descendant Ainu and Paleoamericans (Brace et al., 2001; Jantz and Owsley, 2001). Brace et al. (2001) demonstrated that these samples show craniometric similarity with the prehisotric Jōmon of Japan, the Ainu, and New World populations of modern Native Americans who inhabited the US-Canada border, including the Great Lakes region. This fact may be an indication that the origin of those Native American samples can be traced back to an extended Late Pleistocene stock inhabiting the northern part of the Old World, whose craniofacial morphology differs from that of modern East Asians, but who are descendants of samples related to the prehistoric Jōmon of Japan. Recently, Brace et al. (2008) have suggested that the 9300-year-old Kennewick individual of North America is more closely tied to the recent Ainu of Japan and coastal northeast Asia and their evident ancestors, the prehistoric Jōmon, than to any other population, based on ancient and recent human craniofacial samples from both sides of the Pacific Ocean. Brace et al. (2001, 2008) suggest that the Jomon, who might be the direct descendants of the Paleolithic inhabitants of northeast Asia, have an antiquity greater than that of the first inhabitants of the New World.

Jantz and Owsley (2001, 2003, 2006) also state that Paleoamericans resemble recent circum-Pacific populations like the Ainu and Polynesians. Contra to Brace et al. (2001), Jantz and Owsley explain this phenomenon a different way. They explain that Paleoamericans show resemblance to recent circum-Pacific populations including the Ainu and Polynesians because they have retained Late Upper Paleolithic cranial features to a greater degree than other populations. Moreover, Van Vark et al. (2003) mentioned that there was a relatively strong retention of plesiomorphic characters in peripheral populations between the Late Pleistocene and the present. However, Van Vark et al. suggest that the relatively close morphological affinity of the Late Pleistocene and Early Holocene skulls with those of these recent populations does not necessarily indicate a genetic relationship, hence this may be a poor indicator of the determination of ancestral-descendant relationships between Late Pleistocene and Early Holocene populations. Yet no one can deny the possible genetic relatedness between the Jomon, the Ainu, the Polynesians and the Paleoamericans.

All of the above scenarios note that America was initially colonized by populations that were different from the ancestors of modern Native Americans (Lahr, 1995; Neves et al., 1999; Steele and Powell, 1999, 2002; Brace et al., 2001; Jantz and Owsley, 2001, 2003; Seguchi et al., 2005, 2006; Nelson et al., 2007). Many suggest that the pattern of cranial variation in America over the past 10000 years is more easily explained with reference to two or more colonization events. This hypothesis receives support from genetic data (Schurr et al., 1990; Karafet et al., 1999; Schurr, 2004, 2006). In addition to the above arguments, several anthropologists have suggested that present-day worldwide cranial variation may not have existed at the end of the last glacial period (Lahr, 1992; Powell and Rose, 1999; Powell and Neves, 1999; Neves et al., 1999, 2003, 2005). However, this has never been documented.

Neves et al. (2003, 2005, 2007), Neves and Hubbe (2005), and González-José et al. (2005) have been testing their hypothesis that the origins of Paleoamericans can be traced back to a common ancestor they shared with Australians, although the authors do not include the Jōmon in this analysis. They hypothesize that the ancestor of Paleoamericans departed from somewhere in Southern Asia and arrived on the Australian continent and the Americas around 50000 and 14000 years before present, respectively (Neves et al., 2003). This view also reflects Kamminga and Wright's view (1988) on the Upper Cave 101.

We are aware of the difficulties of the determination of ancestral-descendant relationships between pre-Holocene and recent populations. However, the Paleoamerican remains are necessary for interpreting early New World diversity with the relevant samples and to provide a comparative basis for the morphologies of later populations. The purpose of the present study is to evaluate the affinities of the Lagoa 
Santa with Archaic North American populations and their possible ancestral stock in Northeast Asian region rather than with recent Australian, Melanesian, and African samples.

It has already been shown that the quantitative treatment of craniofacial form can effectively produce a picture of the movement of human populations from Asia into the New World. Moreover, that picture is largely compatible with the picture produced by the molecular genetic comparison of nucleotide haplotypes (Brace et al., 2001). The underlying reason why such different approaches yield comparable results is because neither the nucleic acid components identified nor the particular craniofacial dimensions used have any obvious adaptive value. Both evidently behave in a manner compatible with what has been called the 'neutral theory,' where the traits assessed are under genetic control and the differences between samples are principally the result of genetic drift (Kimura, 1968; Ohta and Kimura, 1971; Brace, 2005; Brace et al., 2006). Craniofacial metric traits that anthropologists choose have no adaptive significance and they provide phylogenies. These traits are both relatively stable over time and highly geographically patterned, suggesting marked regional continuity in time or space (Brace, 2005). For instance, craniofacial configurations show essential continuity in Western Europe and at the eastern edge of Asia of at least 30000 years' duration (Brace and Tracer, 1992). What they show, then, is the extent of genetically shared relationships between adjacent populations. Thus, comparisons between prehistoric skeletal remains from different geographic regions and even different time periods are useful and these comparisons can provide valid clues about the peopling and settlement of the New World (Smith et al., 2006).

This study is aimed at exploring which samples these were, and what their relationships were with other Old World samples and other New World samples. Therefore, we are investigating the morphological affinities of Lagoa Santa with present-day Australians, Melanesians and Africans, prehistoric and modern samples from East and Northeast Asians including the Jōmon, and prehistoric and modern New World samples. This study attempts to understand the diverse history and biological variation in South and North America and connect examinations of the migration between Asia and the North and South American continents by examining craniofacial diversity in multiple time periods. Furthermore, we present an alternative view of the peopling of South and North America.

\section{Materials and Methods}

\section{Materials}

Many have assumed that since Paleoamericans migrated from East Asia across Beringia to America before the end of the Pleistocene, the Paleoamericans would be more closely related to recent Native Americans and East Asians than to any other population (see Van Vark et al., 2003). However, there is limited skeletal evidence in Asia that corresponds to Paleoamericans dated around c. 12000-8500 years in the New World. In East Asia, the only culture that is older, and contemporary to the Paleoamericans in the New World, is the Prehistoric Jōmon of Japan. The Jōmon dates from 13000 to $2300 \mathrm{BP}$ (uncalibrated radiocarbon dates), al- though our Jōmon sample runs from c. 6000 to 2300 years ago. The Neolithic Chinese dated around 7000-5000 BP is another sample contemporary with archaic Americans of the New World. Our archaic populations of the New World are represented by the Indian Knoll, the Windover, the Port au Choix, and the Tennessee archaic samples. The Indian Knoll population represents the archaic period of the Eastern United States (5000-4000 BP), characterized as pre-pottery, pre-agriculture, and hunter-gatherers, and is located near the Green River in Ohio County, Kentucky (Perzigian, 1976; Nelson, 2006). The Windover represents the early middle archaic period of Florida (8000 BP) in the United States, and is characterized as hunter-gatherers (Doran, 2002; Nelson, 2006). The Port au Choix on the west side of Newfoundland's Great Northern Peninsula of North America is a maritime archiac population from c. 4400-3300 BP (Anderson, 1976; Nelson, 2006). The Tennessee archaic discussed here represents the middle archaic period, c. $6000 \mathrm{BC}-3000 \mathrm{BC}$ (Nelson, 2006). The Mongol Bronze Age Chandman specimen from Western Mongolia, dated around 2600-2300 BP, is also included (Brace et al., 2001; Allard and Erdenebaatar, 2005; Nelson et al., 2007).

Although Neves and his colleagues (Neves et al., 2003 , 2005; Neves and Hubbe, 2005) have claimed that early South Americans resemble Australo-Melanesians and Africans, they do not include any Australian specimens from the Late Pleistocene among the reference samples. Unfortunately, we also do not have Australian specimens from the Late Pleistocene. Only modern Australian specimens are used for this analysis.

We compare the craniofacial morphology of four Sumidouro skulls and one Lund skull, representing South American Paleoamericans from Lagoa Santa, Brazil, dated at 9000 $\mathrm{BP}$, and housed in the Institute of Zoology in Copenhagen, Denmark, with worldwide prehistoric and recent human craniofacial metric data. We use the UMMA (University of Michigan Museum of Anthropology) worldwide craniofacial metric database for the comparative samples in this study (Table 1).

Only the 31 best preserved skulls from the Jomon were used in this analysis, in order to minimize the replacement of missing values. Missing values of the Jōmon sample were replaced by a multivariate sequential regression for imputation (Raghunathan et al., 2004).

\section{The use of craniometrics as quantitative genetic data and problems of craniometric variables}

Morphological detail is quantified through the statistical analysis of craniofacial metric variables. Metric dimensions depict variations in cranial bone size and shape; in essence, this refers to the details in the construction of the cranial vault and face. These craniofacial metric traits are complex traits and quantitative genetic traits, and quantitative genetic data must reflect the underlying complex genetic information (Nelson, 2006; Nelson et al., 2007). However, variation for quantitative traits can be influenced not only by many Mendelian loci, but also environmental effects. Because the degrees of 'environmental influence' are unknown, there are still arguments and questions about the use of craniofacial morphology as a legitimate tool to recover recent human 
Table 1. Populations used in present study

\begin{tabular}{|c|c|c|c|c|}
\hline Population & Remarks & Female & Male & Total \\
\hline \multicolumn{5}{|l|}{ East Asia and Northeast Asia } \\
\hline Jōmon* & $6000-2000 \mathrm{BP}$ & 14 & 17 & 31 \\
\hline Japanese & Modern & 100 & 217 & 317 \\
\hline Ainu & 1500 AD?-Modern & 23 & 33 & 56 \\
\hline Atayal & Modern & 14 & 22 & 36 \\
\hline Mongol & Modern & 21 & 29 & 50 \\
\hline Mongol Bronze Age (Chandman)** & 2600-2300 BP (from West Mongol) & 25 & 29 & 54 \\
\hline China Bronze Age & $4000 \mathrm{BP}$ & 16 & 45 & 61 \\
\hline Heilonjiang & Modern & 8 & 10 & 18 \\
\hline North China & Modern & 24 & 38 & 62 \\
\hline South China & Modern & 43 & 84 & 127 \\
\hline China & Modern & 89 & 102 & 191 \\
\hline Buriat & Modern & 14 & 12 & 26 \\
\hline Chukchi & Modern & 7 & 12 & 19 \\
\hline \multicolumn{5}{|l|}{ Southeast Asia } \\
\hline Burma & Modern & 15 & 21 & 36 \\
\hline Thai & Modern & 27 & 37 & 64 \\
\hline Java & Modern & 1 & 4 & 5 \\
\hline \multicolumn{5}{|l|}{ South Asia } \\
\hline South Asia (India) & Modern & 20 & 31 & 51 \\
\hline \multicolumn{5}{|l|}{ Europe } \\
\hline West Europe & Modern & 111 & 152 & 263 \\
\hline \multicolumn{5}{|l|}{ Africa } \\
\hline West Africa & Modern & 51 & 54 & 105 \\
\hline Bushman/Hottentots & Modern & 3 & 9 & 12 \\
\hline Sudan & Historic & 5 & 10 & 15 \\
\hline \multicolumn{5}{|l|}{ New World } \\
\hline Athabascan & Historic & 23 & 19 & 42 \\
\hline Eskimo & Historic & 63 & 77 & 140 \\
\hline Aleut & Historic & 15 & 17 & 32 \\
\hline Chumash & Historic & 25 & 29 & 54 \\
\hline Tennessee archaic ${ }^{\#}$ & Middle archaic (6000-3000 BP) & 10 & 19 & 29 \\
\hline Indian Knoll ${ }^{\%}$ & Riverine archaic (5000-4000 BP) & 19 & 22 & 41 \\
\hline Windover $\$$ & Early Middle archaic (8000 BP) & 17 & 15 & 32 \\
\hline Port au Choix $\$$ & Maritime archaic (4400-3300 BP) & 10 & 8 & 18 \\
\hline Mexico & Historic & 11 & 17 & 28 \\
\hline Peru & Historic & 29 & 26 & 55 \\
\hline Patagonia & Historic & 4 & 9 & 13 \\
\hline Terra del Fuego & Historic & 7 & 15 & 22 \\
\hline \multicolumn{5}{|l|}{ Pacific } \\
\hline Polynesia & Modern & 87 & 74 & 161 \\
\hline Papua New Guinea & Modern & 4 & 6 & 10 \\
\hline Melanesia & Modern & 30 & 37 & 67 \\
\hline Australia & Modern & 19 & 28 & 47 \\
\hline \multicolumn{5}{|l|}{ Paleoamericans } \\
\hline Lagoa Santa & $9000 \mathrm{BP}$ & 2 & 3 & 5 \\
\hline Total & & 1074 & 1465 & 2539 \\
\hline
\end{tabular}

* Jōmon from Early (Kitakogane, Myoonji), Middle (Wakami, Ohta, Irie), Late (Yoshigo, Tsukumo, Takasago, Funadomari), to the latest Jōmon periods (Miyano, Takasago).

** From Brace et al. (2001), Allard and Erdenebaatar (2005), and Nelson et al. (2007).

*** Neolithic Chinese mainly from Yang Shao.

\# From Nelson (2006).

${ }^{\%}$ From from Perzigian (1976) and Nelson (2006).

$\$$ From Doran (2002) and Nelson (2006).

$\$ \$$ From Anderson (1976) and Nelson (2006).

evolutionary and population history (Relethford, 2004).

For instance, some of the cranial features that Neves et al. $(2003,2005,2007)$ and Neves and Hubbe (2005) use to char- acterize the Early Brazilian Paleoamericans are maximum cranial length, maximum cranial breadth, and alveolar prognathism. These variables in particular have been criticized 
with allegations that cranial morphology, such as dolichocephaly, brachycephaly, and alveolar prognathism, is supposedly very plastic in nature and responds rapidly to local prevailing environmental conditions (see Boas, 1912 for the origin of this idea; Suzuki, 1963, 1969; Necrasov, 1974; Jantz, 2000; Jantz and Meadows, 2000; Kouchi, 2000; Mizoguchi, 2000; Seguchi, 2000; Okazaki, 2004; Roseman, 2004; Harvati and Weaver, 2006; Hubbe et al., 2009). As such, some argue that cranial morphology would not be a reliable marker to trace ancestral-descendant relationships (Carlson and Van Gerven, 1977; Van Vark et al., 2003). Furthermore, long cranial length can be simply an ancient trait because there might be selection for robustness.

Relethford (2004) claims that the change caused by possible environmental influences on cranial length and cranial breadth do not necessarily obscure ancestor-descendant relationships. Several researchers also note that the potential environmental influences acting upon the development of craniofacial form are insufficient; therefore these influences do not play a major role in changes of overall morphological differences (Lahr and Wright, 1996; Relethford, 2002; Sparks and Jantz, 2002; González-José et al., 2004, 2005; Neves and Hubbe, 2005; Neves et al., 2005; Betti et al., 2010).

It is true that both the maximum cranial length and breadth contain ancestral information. However it appears that people's movements in Asia are not simple. There are no definite routes of the ancient expansion of Asian populations. These routes could be from the south (from Africa, South Asia, Australia, and Southeast Asia) to the north (East Asia and Northeast Asia); or the routes could be from the north (from Europe via Siberia) to the east (to Northeast Asia and East Asia). Because of possible complex migration routes, ancestral information that is expressed in cranial length and breadth might have shown rapid secular change, so using these variables may not be the best idea. Therefore, we tested both inclusion (21 variables) and exclusion (19 variables) of maximum cranial length and maximum cranial breadth. These results will be shown in this study for comparative purposes (definition in Table 2).

\section{Statistical procedures}

We employed the R-matrix method on the craniometric data in this study. The R-matrix method was originally proposed by Harpending and Jenkins (1973) for allele/ haplotype frequency data, and was further expanded to quantitative traits by Williams-Blangero and Blangero (1989) and Relethford and Blangero (1990). Given data on means and an estimate of average heritability, an R-matrix can be estimated from quantitative traits, such as craniometric or odontmetric traits (Relethford, 2007). An R-matrix provides estimates of genetic similarities and distances within and among populations relative to the contemporary means of allele frequencies in a region (Relethford, 1991; Relethford and Harpending, 1994). R-matrix analyses make clear-cut assumptions regarding the mode of transmission of the underlying genotypic variation expressed in the phenotype, and in evolutionary and demographic parameters affecting population structure (Williams-Blangero and Blangero, 1989; González-José et al., 2005). Recently, the
Table 2. Craniofacial measurements used in this study

\begin{tabular}{ll}
\hline 1. Nasal height & Martin No. 55 \\
2. Nasal bone height & Martin No. 56 [2] \\
3. Piriform aperture height & Martin No. 55 [1] \\
4. Nasion prosthion length & Martin No. 48 \\
5. Nasion basion & Martin No. 5 \\
6. Basion prosthion & Martin No. 40 \\
7. Superior nasal bone width & Martin No. 57 [2] \\
8. Simotic width & Howells (1973) \\
9. Inferior nasal bone width & Martin No. 57 [3] \\
10. Nasal breadth & Martin No. 54 \\
11. Simotic subtense & Howells (1973) \\
12. Inferior simotic subtense & Brace and Hunt (1990) \\
13. Fronto orbital width subtense at nasion & Woo and Morant (1934) \\
14. Mid-orbital width subtense at rhinion & Woo and Morant (1934) \\
15. Bizygomatic breadth & Martin No. 45 \\
16. Glabella opisthocranion* & Martin No. 1 \\
17. Maximum cranial breadth* & Martin No. 8 \\
18. Basion bregma & Martin No. 17 \\
19. Basion rhinion & Brace and Hunt (1990) \\
20. Width at 13 (frontomalar temporalis) & Brace and Hunt (1990) \\
21. Width at 14 (mid-orbital width) & Woo and Morant (1934)
\end{tabular}

${ }^{1}$ Martin numbers are from Martin (1928).

* 19 variables: without glabella opisthocranion (maximum cranial length) and maximum cranial breadth.

R-matrix/Relthford-Blangero method has been applied by many researchers to quantitative morphological traits to search population relationships and/or population structure (Relethford, 1991, 1994; Relethford and Harpending, 1994; Powell and Neves, 1999; Steadman, 2001; González et al., 2003; González-José et al., 2004, 2005; Roseman and Weaver, 2004; Stojanowski, 2004, 2005; Hanihara and Ishida, 2005, 2009; Hanihara et al., 2008).

Because phenotypic traits are not completely under genetic control, the R-matrix method assesses using estimates of the average heritability of phenotypic traits. Various studies have published the heritability estimates of craniometric traits (Sjøvold, 1984; Devor, 1987; Sparks and Jantz, 2002). According to Relethford and Harpending (1994), heritabilities for craniometric traits are fairly stable across populations, and an average estimation of $h^{2}=0.55$ that is based on Devor's study (1987) can be used. Most recently, Carson (2006) published narrow-sense heritability estimates for 33 craniometric dimensions using the maximum likelihood variance components method on a skeletal sample of pedigreed individuals from Hallastatt, Austria. In her study, she found low heritability estimates of most bilateral breadth measurements, while cranial length and height dimensions have heritability values ranging between 0.102 and 0.729 (Carson, 2006). The common practice of many researchers using the R-matrix method for human craniometric data is to average the reported narrow-sense heritabilities $\left(h^{2}=0.55\right)$, which is a measure of the proportion of the total phenotypic variance that is due to additive genetic variance, or to assume that the phenotypic correlation is equivalent to the genotypic correlation $\left(h^{2} \approx 1.0\right)$ (Carson, 2006). Assuming heritabilities equal to 1 , the distance matrix obtained represents a matrix containing the minimum genetic/biological distances derived from phenotypic variation (Williams-Blangero and Blangero, 1989; Relethford and Blangero, 1990). 
Relethford and Blangero (1990) concluded that as long as the narrow-sense heritability for a trait was greater than 0.2 , the relative pattern of genetic/biological distances between populations did not change significantly, although the absolute genetic/biological distances do change, given different heritabilities. Using the R-matrix method, overall environmental effects are removed by using an estimate of the overall average of heritability of all variables (Relethford, 2007). In this study, we follow Relethford's overall average heritabilities, and take $h^{2}=0.55$.

Despite the fact that sample sizes are low, the use of averages and multivariate centroids of such samples must be of interest in the perception of general tendencies by means of classical statistics. Therefore, a principal coordinate plot based on an R-matrix can still be a useful tool to test population relationships. As a first step, all data were standardized to $z$-scores within each sex to remove sex-related size variation (Williams-Blangero and Blangero, 1989). Since we have noticeably small sample-size samples, we computed biological distances after adjusting for small sample size bias following Relethford et al. (1997). The biological distances were obtained after an R-matrix analysis (Relethford, 1991; Relethford et al., 1997). The biological distances between samples generated by R-matrix analysis are roughly proportional to Mahalanobis distances (Relethford, 1991). The neighbor-joining method was applied based on biological distances generated by $\mathrm{R}$ matrices (Saitou and Nei, 1987). The web-like trees (SpritsTree 4.6: Huson and Bryant, 2006) were generated by the neighbor-joining method from biological distances by the R-matrix analysis and generated from batteries of 19 measurements and 21 measurements on samples of each of the population samples named, in order to examine for affinities between samples. The R-matrix and the Relethford-Blangero methods were programmed by one of the present authors (H.U.).

Dealing with small sample size or the case of isolated individuals, it is possible that these specimens can be far from the group centroid; therefore they could be outliers of the population. When studying single specimens, we must be cautious because the central tendency of the population from which the specimen was extracted is unknown (GonzálezJosé et al., 2005). These five samples may not be representative of Lagoa Santa. Therefore, we considered another approach. Recent advances in multivariate analyses enable assessment of craniometric affinities of a single specimen to reference samples of other modern and historical populations (Albrecht, 1992; Van Vark and Schaafsma, 1992; Brace et al., 2006). We test for the presence of Paleoamerican morphology in South America and North America by analyzing the affinities between five early skulls from Lagoa Santa and worldwide prehistoric and modern reference samples. Individuals of Brazilian Paleoamericans were examined by typicality probabilities and Mahalanobis distances (Albrecht, 1992).

First, Mahalanobis distances were computed between the five early Brazilian skulls individually and a set of reference samples, including Jōmon, Ainu, Taiwan Atayal, Japan, North China, South China, China, Neolithic China, China Bronze Age, Heilongjiang, Mongol, Mongol Bronze Age (Chandman), Buriat, Thai, Burma, Borneo, Java, Polynesia,
West Europe, West Africa, Sudan, Bushman/Hottentot, Australia, South Asia, Sepik River Papua New Guinea, Tierra del Fuego, Peru, Mexico, Patagonia, Blackfoot, Great Lakes, Mississippian (Dickson Mound, Illinois; Moundville, Alabama), Windover (Florida archaic), Port au Choix (Newfoundland archaic), Tennessee archaic, Indian Knoll (Kentucky archaic), Snake River sample of Washington State, Chumash sample of California, Athabascan, Eskimo, and Aleut. Then, to make more meaningful statements about the affinities of the individuals for the reference samples, we computed typicality probabilities using F-distribution from the Mahalanobis distances (Brace et al., 2006).

The Relethford and Blangero (1990) analysis detects deviations from an equilibrium between gene flow and genetic drift derived from observed and expected values of withingroup phenotypic variance. Under the Relethford-Blangero model, positive residuals for a particular population may reflect: (a) higher levels of long-range gene flow from an 'outside' source (Relethford and Blangero, 1990), resulting in greater heterozygosity; (b) a higher mutation rate than other samples considered; (c) a larger effective population size or different timing of population growth than other populations (Relethford and Harpending, 1995); or (d) non-random sampling effects or population pooling that artificially inflate within-group variance. Unfortunately, it is inappropriate to assess variation among only five Lagoa Santa specimens; however, we performed the Relethford-Blangero analysis among the early and late Holocene New World populations and the temporal ancient East Asian populations. We calculated R-matrix under the assumption of equal effective population size, then we calculated using an estimated census population size for Lagoa Santa.

\section{Results and Discussion}

Both principal coordinate plots of Lagoa Santa and the Old World samples using 19 variables (Figure 1) and 21 variables (Figure 2) separate the group of Africa, South Asia, Australia, and Melanesia from the samples of East Asia, Northeast Asia, Southeast Asia, Polynesia, and Europe. In the first and second eigenvector plots of 19 variables, Lagoa Santa clusters with West Europe, Jōmon and Mongol Bronze Age (Figure 1a). But the first and second coordinate (eigenvector) plot of 21 variables (Figure 2a) places Lagoa Santa between Jōmon/Ainu and South Asia, Sudan, and Australia. The second and third coordinate (eigenvector) plot of 19 variables (Figure 1b) indicates that Lagoa Santa is located closer to the Jommon, Ainu, and Polynesian than to the Australian, Melanesian, and African samples. The second and third eigenvector plot of 21 variables (Figure 2b) also shows a similar picture to the plot of 19 variables, placing even Heilongjiang and Chukchi closer to Lagoa Santa. When the Jomon is removed from these samples, the first and second coordinate (eigenvector) plot of 21 variables (Figure 3a) suggests that Lagoa Santa is placed a little closer to South Asia and Australia and Sudan than Ainu, but the second and third coordinate (eigenvector) plot (Figure 3b) shows that Lagoa Santa is closer to Ainu, Heilongjiang, and Chukchi than Australia. Neves et al. $(2003,2005,2007)$ and Neves and Hubbe (2005) might have 
Scaled Eigenvectors(unbiased) $h^{2}=0.55 ; F_{s t}=0.222 ; E V 1, E V 2, E V 3=33.1,18.0,12.6(\%)$
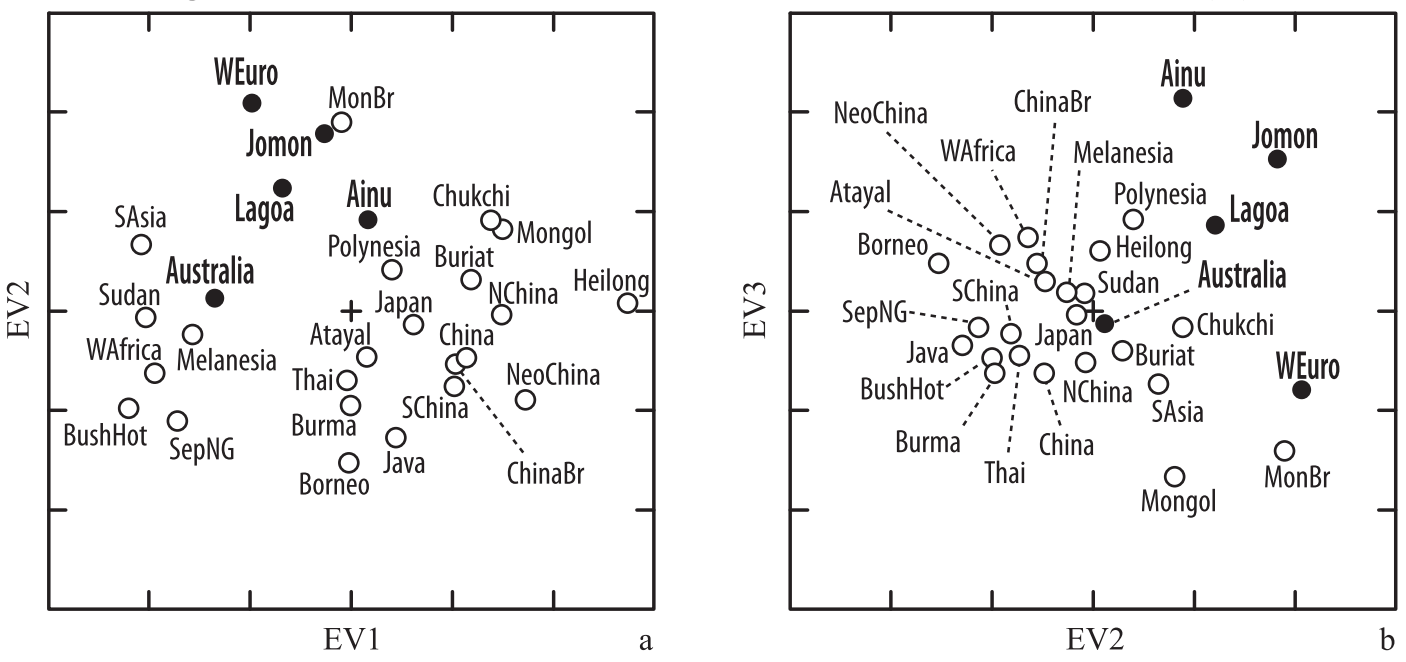

$\begin{array}{lcll} & \text { Weight } & & \\ \text { A: Jomon } & 1 & \text { O: ChinaBr } & 1 \\ \text { B: Ainu } & 1 & \text { P: wEuro } & 1 \\ \text { C: Atayal } & 1 & \text { Q: MonBr } & 1 \\ \text { D: Japan } & 1 & \text { R: Chukchi } & 1 \\ \text { E: NChina } & 1 & \text { S: Buriat } & 1 \\ \text { F: SChine } & 1 & \text { T: Australia } & 1 \\ \text { G: China } & 1 & \text { U: WAfrica } & 1 \\ \text { H: NeoChina } & 1 & \text { V: Sudan } & 1 \\ \text { I: Heilong } & 1 & \text { W: BushHot } & 1 \\ \text { J: Mongol } & 1 & \text { X: Lagoa } & 1 \\ \text { K: Thai } & 1 & \text { Y: SAsia } & 1 \\ \text { L: Burma } & 1 & \text { Z: SepNG } & 1 \\ \text { M: Borneo } & 1 & \text { 1: Melanesia } & 1 \\ \text { N: Java } & 1 & \text { 2: Polynesia } & 1\end{array}$

Figure 1. Principal coordinate plot using 19 variables (the first and second eigenvectors), using $h^{2}=0.55$ and relative weights of 1.0 for all samples. (a) The first and second eigenvectors. (b) The second and third eigenvectors.

seen this picture (especially the first and second eigenvector plot) in their analysis, which excludes the Jommon and Northeast Asians (also see the NJ tree of Figure 4). Excluding the Jōmon from the samples, we also see a similar picture: Lagoa Santa ties to South Asia, which also shares a node with West Europe (Figure 4). The Ainu ties to Polynesia.

In the neighbor-joining trees which were generated by the same R-matrix using 19 variables that include the Jomon, East and Southeast Asian samples, Africa, Pacific, Europe, and South Asia without the New World samples (Figure 5), Lagoa Santa ties to the Jomon, Ainu, South Asia, and Europe. Even when 21 variables are used (Figure 6), these pictures are very similar to those that use 19 variables. The numbers of variables has little influence on the results of biological distances in these cases. In fact, Lagoa Santa, the Jomon, and Ainu show craniometric similarity to the European Upper Paleolithic specimens (varying from 30000 to 15000 years old, such as Cro-Magnon 1, Předmost 3, Le Placard, Abri Pataud, Ronde du Barry, Saint Germain, and Obercassel 1). Hence Lagoa Santa ties to West Europe (not shown). If the Late Pleistocene populations in Northwest Europe and Northeast Asia suggest that there may have been actual genetic ties at one time because of their morphological similarities (Brace et al., 2001), it is no surprise to see the similarities between Lagoa Santa and West Europe since morphological similarities can still be shown between Europe and the descendants of the aboriginal population of the Japanese archipelago, i.e. Jōmon and Ainu.

Figure 7 and Figure 8 illustrate the results of trees of previous samples, adding the New World samples, including archaic American samples, and historic and modern native samples of North America, Central America and South America. It is no surprise to discover that samples of the New World tie together, except for Aleut, Eskimo, and Athabascan samples. The Athabascans, Aleut, and Eskimo tie more closely to the Chinese core samples. In the tree using 19 variables, Lagoa Santa closely ties to the archaic Indian Knoll, and is located at the next branch with the cluster of the Jōmon and Ainu (Figure 7). These samples make a cluster of the historical Central and South American samples and the California coastal group, the Chumash. Other archaic samples such as Windover, Tennessee archaic, and Port au Choix, and Mississippians, the historic Great Lakes and Blackfoot, and the Mongol Bronze Age make a sub-cluster. Australian, Melanesian, and African samples form one cluster. In the tree using 21 variables (Figure 8), Lagoa Santa ties to Windover, and Indian Knoll, Tennessee archaic, and Mississippians, in addition to the Great Lakes, Port au Choix, Mongol Bronze Age Chandman, and Blackfoot. Even including maximum cranial length and cranial breadth, 

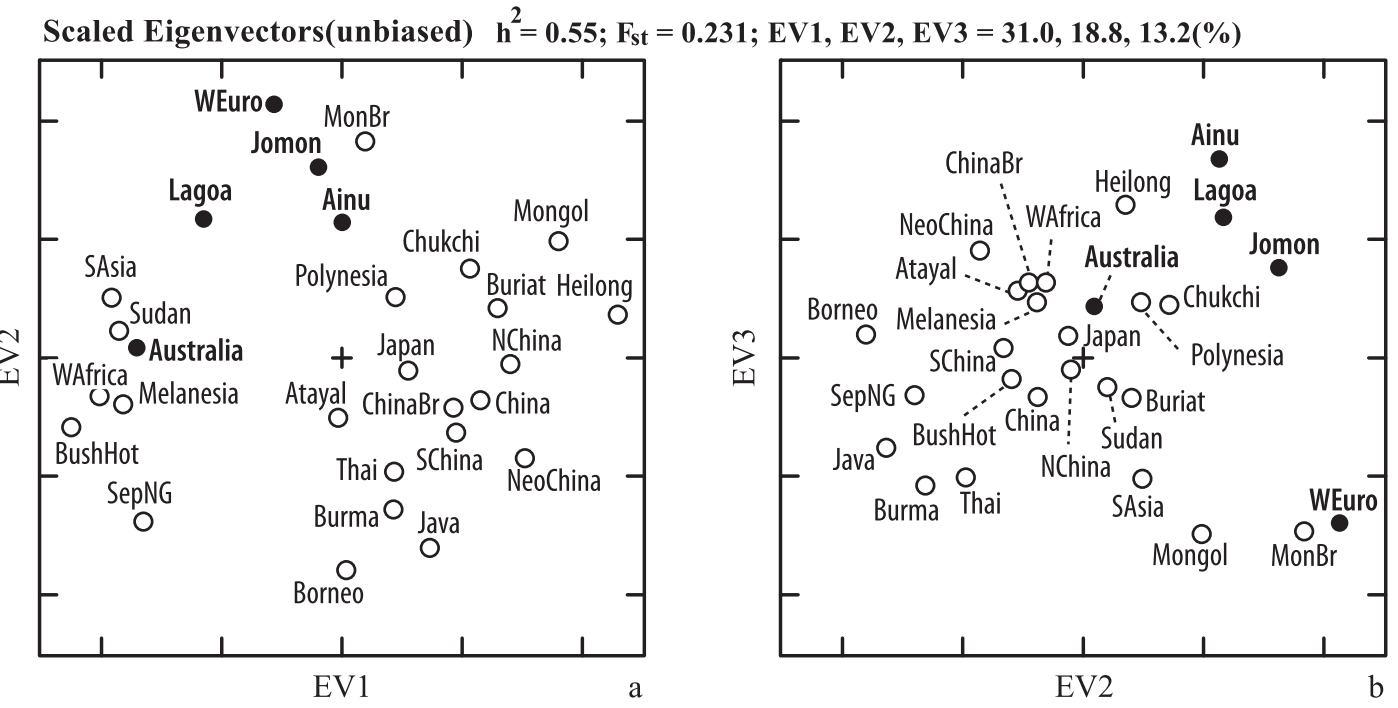

$\begin{array}{lcll} & \text { Weight } & & \\ \text { A: Jomon } & 1 & \text { O: ChinaBr } & 1 \\ \text { B: Ainu } & 1 & \text { P: wEuro } & 1 \\ \text { C: Atayal } & 1 & \text { Q: MonBr } & 1 \\ \text { D: Japan } & 1 & \text { R: Chukchi } & 1 \\ \text { E: NChina } & 1 & \text { S: Buriat } & 1 \\ \text { F: SChine } & 1 & \text { T: Australia } & 1 \\ \text { G: China } & 1 & \text { U: WAfrica } & 1 \\ \text { H: NeoChina } & 1 & \text { V: Sudan } & 1 \\ \text { I: Heilong } & 1 & \text { W: BushHot } & 1 \\ \text { J: Mongol } & 1 & \text { X: Lagoa } & 1 \\ \text { K: Thai } & 1 & \text { Y: SAsia } & 1 \\ \text { L: Burma } & 1 & \text { Z: SepNG } & 1 \\ \text { M: Borneo } & 1 & \text { 1: Melanesia } & 1 \\ \text { N: Java } & 1 & \text { 2: Polynesia } & 1\end{array}$

Figure 2. Principal coordinate plot using 21 variables, applied $h^{2}=0.55$ and relative weights of 1.0 for all samples. (a) The first and second eigenvectors. (b) The second and third eigenvectors.

Lagoa Santa closely located to archaic Americans and Jōmon and Ainu samples. Our analyses do not support Neves's claims for a probable Melanesian or Australian source for the Lagoa Santa.

As Lahr $(1995,1996)$ concluded, Fuegians and Patagonians fail to cluster into the 'typical' Northeast Asian descent morphological pattern. In our analysis, Tierra del Fuego and Patagonians are tied to geographically close samples, such as Mexico, Peru, even Lagoa Santa, and the Jōmon and Ainu rather than the Chinese core samples. Additionally, the Jōmon and Ainu are more closely tied to the New World samples than to the Chinese core samples. Table 3 shows the biological distances generated by Rmatrix using 19 variables between the reference samples and Lagoa Santa, Jomon, Australia, Melanesia, Indian Knoll, and Tennessee archaic. Figure 7 and Figure 8 together with the biological distances given in Table 3 again support the view that Australia, Melanesia, and African samples are not closely tied to Lagoa Santa.

The intention of typicality probabilities (tp) is to determine the probabilities of a skull falling within the multivariate normal distribution of one of the reference samples. The low typicality probabilities across the reference samples indicate that the individual falls outside the range of the reference group (Albrecht, 1992). Among researchers, the computa- tion of typicality probabilities has been a controversial issue. There is a lack of consensus about using the method, and it seems that the different numbers of variables may affect the results (Jantz and Owsley, 2003; Van Vark et al., 2003; González-José et al., 2005). However, showing Mahalanobis distances and typicality probabilities gives us more numerical sense than canonical variate plots and trees (Table 4). The pattern of distances to reference samples from the five individuals is somewhat constant. The Early Brazilian skulls show clear resemblance to archaic North American samples: Indian Knoll, Tennessee archaic, Windover, Port au Choix; the Jōmon of Japan; historical South Americans (Tierra del Fuego, Peru, and Mexico); and historical North Americans (Chumash and Blackfoot). As Neves and collaborators (Neves et al., 2003, 2005; Neves and Hubbe, 2005) claim that their larger sample size of Lagoa Santa shows more similarity to Melanesians, Australians, and Africans than Asians, our Sumidouro 9 displays the nearest Mahalanobis distances to the Atayal and Melanesians, before the Jōmon and Burma. However, the typicality probability of Jōmon is still large $(\mathrm{tp}=0.567)$. All Mahalanobis distances and typicality probabilities for the Lagoa Santa specimens are shown in Table 4 . Now we compare these results to Neves's results (Neves et al., 2007). In their computation, the closest reference of Sumidouro 3 is 


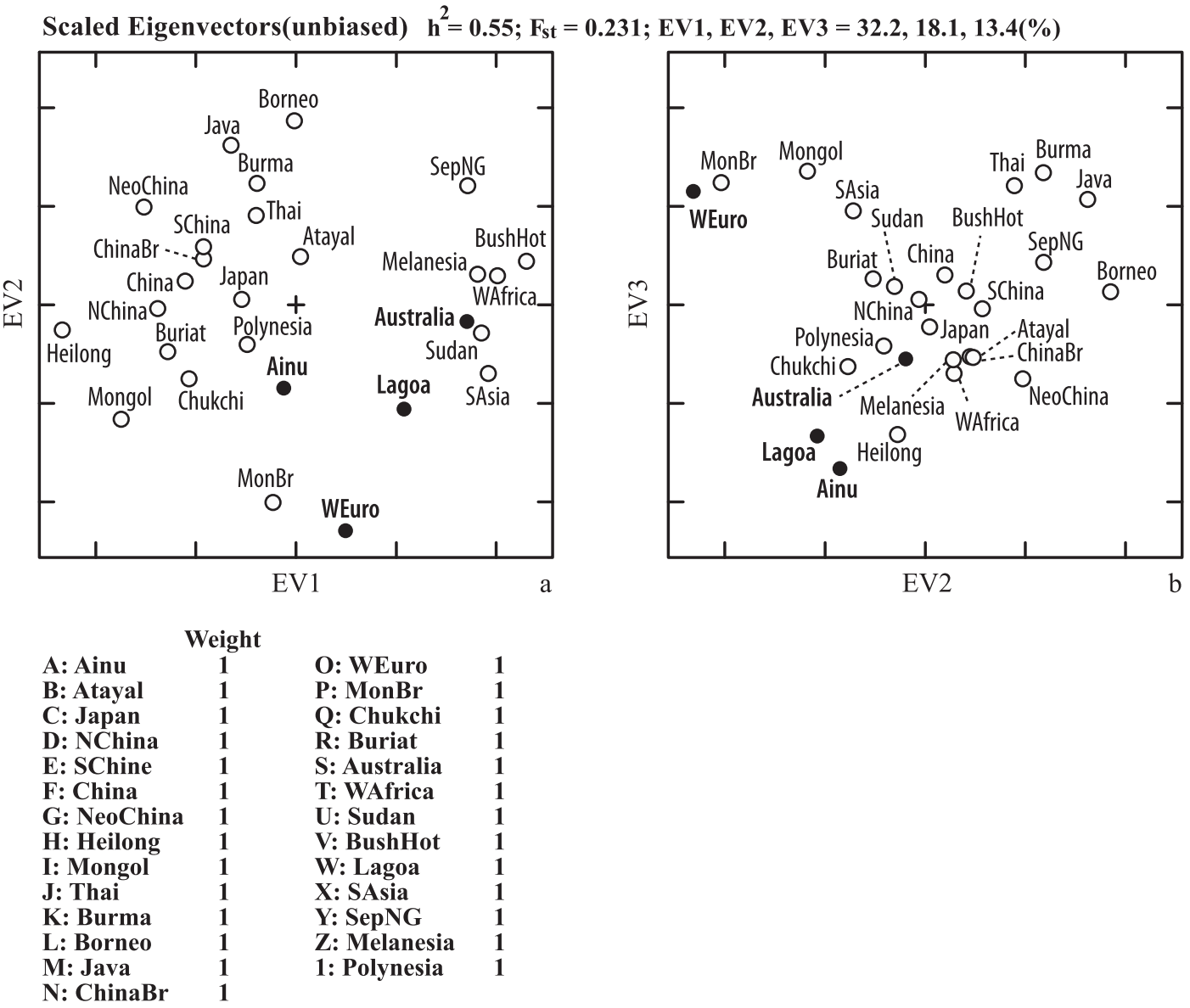

Figure 3. Principal coordinate plot using 21 variables, applied $h^{2}=0.55$ and relative weights of 1.0 for all samples. (a) The first and second eigenvectors. (b) The second and third eigenvectors. These plots are generated without the Jomon.

Teita; Sumidouro 4 is Guam; Sumidouro 9 is Atayal; and Sumidouro 16 is Atayal. Our computation results of Mahalanobis distances and typicality probabilities of Sumidouro 3 and 4 are different from those of Neves et al. (2007) because they did not include the Jomon, the Archaic Americans in North America, and the historic South American samples, and we obtained the closest reference series of our results of Sumidouro 3 and 4 from the reference samples that Neves et al. (2007) did not include. However, the belongingness of the closest reference samples of Sumidouro 9 and 16 in our analysis do not contradict Neves' results (Table 4), although their typicality probabilities have a less than $5 \%$ chance of belonging to their closest reference sample (Neves et al., 2007). Furthermore, the Mahalanobis distances between Sumidouro 9 and 16, and the Jömon of Japan, are small, and typicality probabilities are high in our analysis.

To summarize, analyses of individual skulls against reference samples suggest that the Early Brazilian Lagoa Santa individuals exhibit stronger morphological affinities with the archaic of Indian Knoll, Tennessee and the Windover of North America and the prehistoric Jōmon of Japan than with our Melanesian and Australian samples. Moreover, Lagoa Santa shows partial similarity with East Asian such as Atayal.

Although the number of craniometric variables (inclusion and exclusion of maximum cranial length and maximum cranial breadth) seems to minimally influence the results of the analysis, it appeared not to obscure the ancestral and descendant relationships, and displays clear regional kin relationships in the case of this study. This may suggest that selective forces on skulls can be considered as neutral on average (Brace et al., 2001, 2006; Relethford, 2004; Betti et al., 2010), and multivariate statistical methods must reflect somewhat genetic differences between samples (GonzálezJosé et al., 2005). At the very least, this study supports continuity between Early Brazilian Lagoa Santa and archaic samples of North America and with Central and South American samples.

Furthermore, Neves et al. (2005) used modern samples of the Old World, including Australian Aborigines, Ainu, Basques, and Portuguese; modern North and South Americans samples and Paleoamericans, excluding Lagoa Santa and Sumidouro, ranging from 10000 to 8000 years old; and the Liujiang and Upper Cave Zhoukoudian 101 from China. The results of canonical analysis using the previous samples indicate that the sample from Australia appears to be an outlier (see Neves et al., 2005, Figure 4). In this result, they considered only the first root of principal component analysis and concluded that the Australian presents values within the dispersions of the Paleoamericans. Neves et al. (2005, 


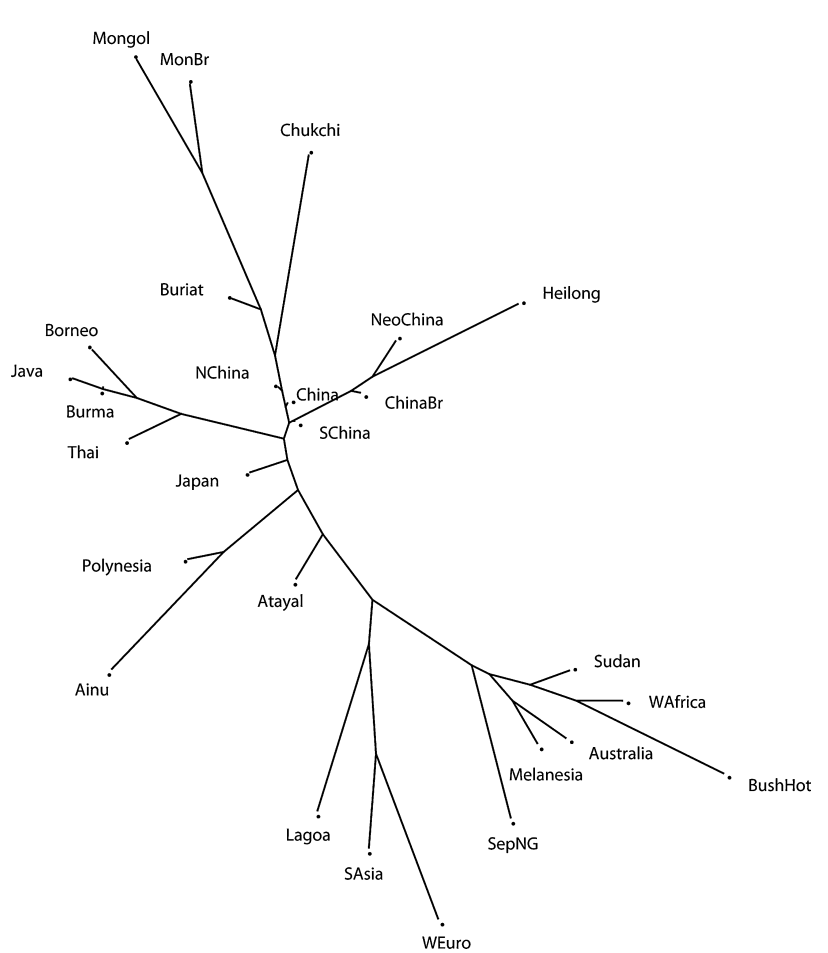

Figure 4. The neighbor-joining tree using 21 variables for the same samples represented in without the Jōmon and the New World.

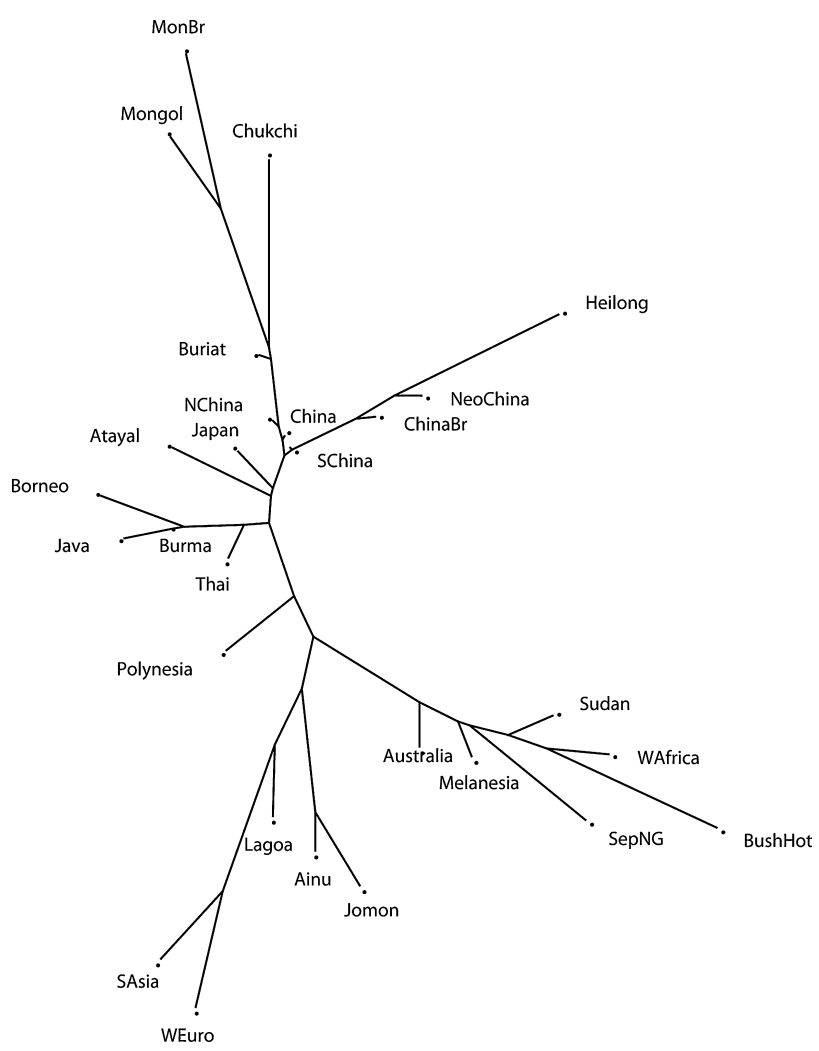

Figure 5. The neighbor-joining tree using 19 variables including the Jōmon, but excluding the New World samples.

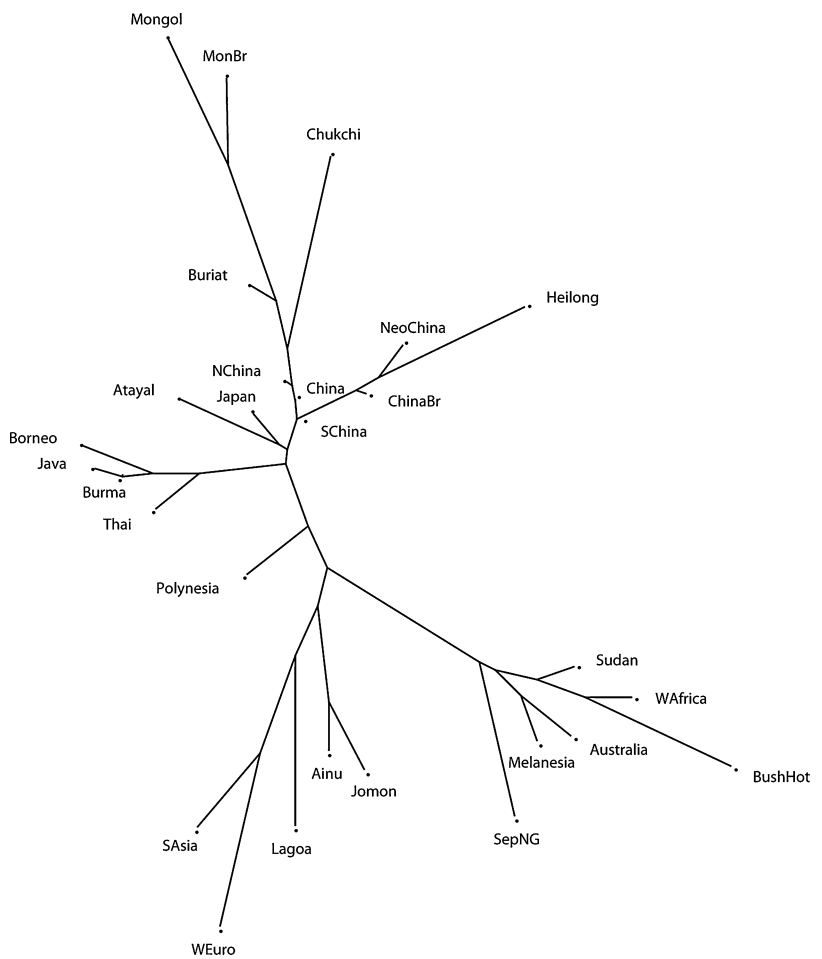

Figure 6. The neighbor-joining tree using 21 variables including the Jōmon, but excluding the New World samples.

2007) and Neves and Hubbe (2005) repeatedly emphasize that Sumidouro specimens have similarities with other early specimens from Lagoa Santa; their morphological characteristics are long and narrow neurocrania, low and wide orbits, and low and wide noses. Neves et al. claim moreover that those characteristics are only found among Africans and Australo-Melanesians, although Jantz and Owsley (2003, 2006) documented that the Paleoamercans' crania are not even uniformly long-headed, and some Paleoamericans exhibited mesocrania and short and wide crania. Our analysis, both including and excluding maximum cranial length and maximum cranial breadth, do not support the AustraloMelanesians origins of Lagoa Santa in the case of this study. In addition, when the Upper Cave Zhoukoudian 101 was tested with Australians, East Asians including Mongolian Bronze Age, and Archaic North Americans, we found that the allocation of the Upper Cave Zhoukoudian 101 was closest to Mongolian Bronze Age, closer than Australians or Neolithic Chinese (Seguchi, 2004). The Mongolian Bronze Age sample is unrelated to modern Mongols and has more in common with prehistoric Europeans and the Native Americans of the US-Canada border (Brace et al., 2001, 2006). These results suggest that the Upper Cave 101 might share a genetic stock with the Paleoamericans. Our analyses support that the Paleoamericans in South America and the early North Americans' cranial patterns are different from today's Northeastern Asians (Powell and Neves, 1999; Brace et al., 2001; Jantz and Owsley, 2001; Neves et al., 2005, 2007; Neves and Hubbe, 2005; Nelson, 2006; Nelson et al., 2007). However, our results do not support the detection of an 'Australo-Melanesian' pattern of cranial 


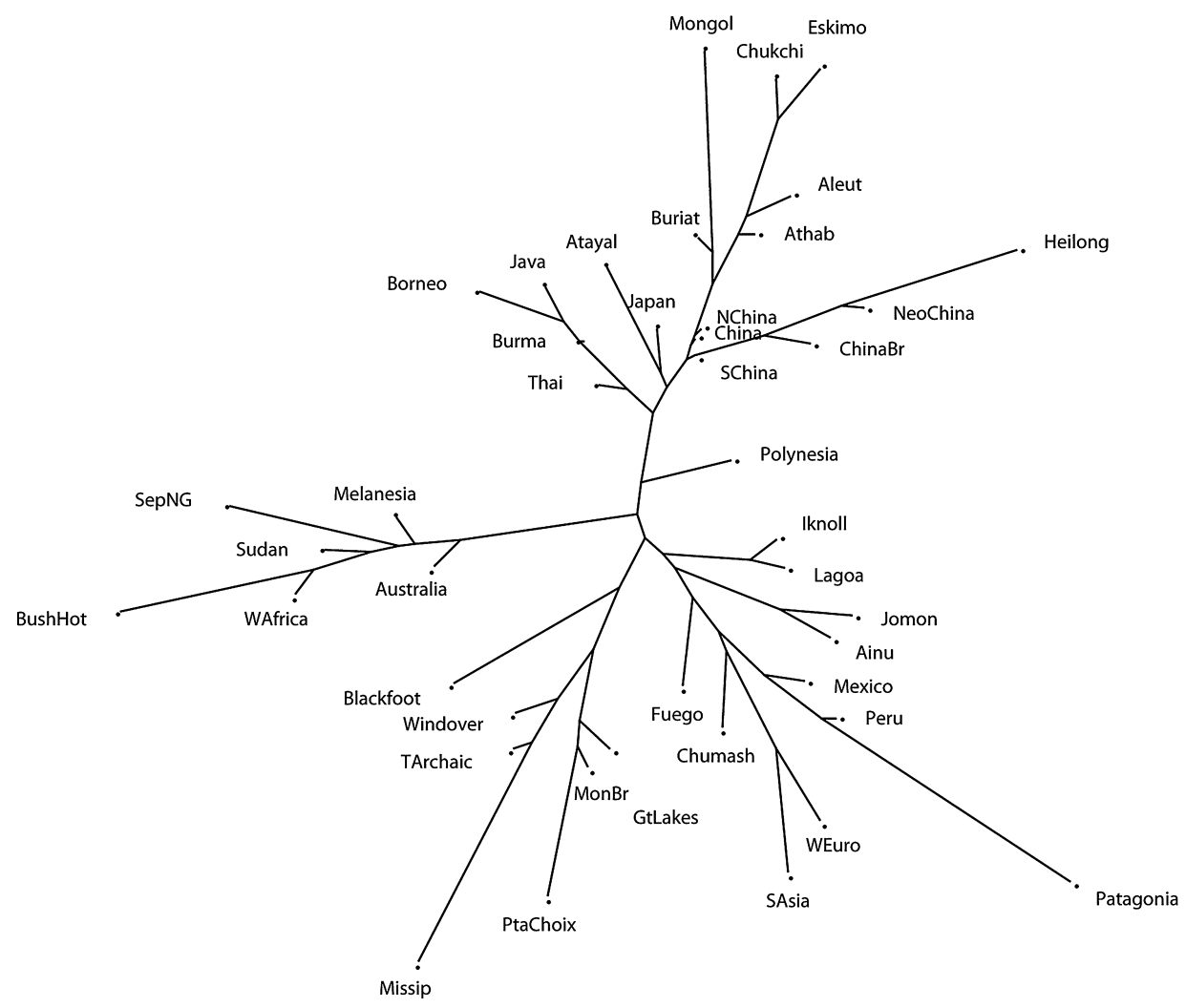

Figure 7. The neighbor-joining tree using 19 variables with all reference samples.

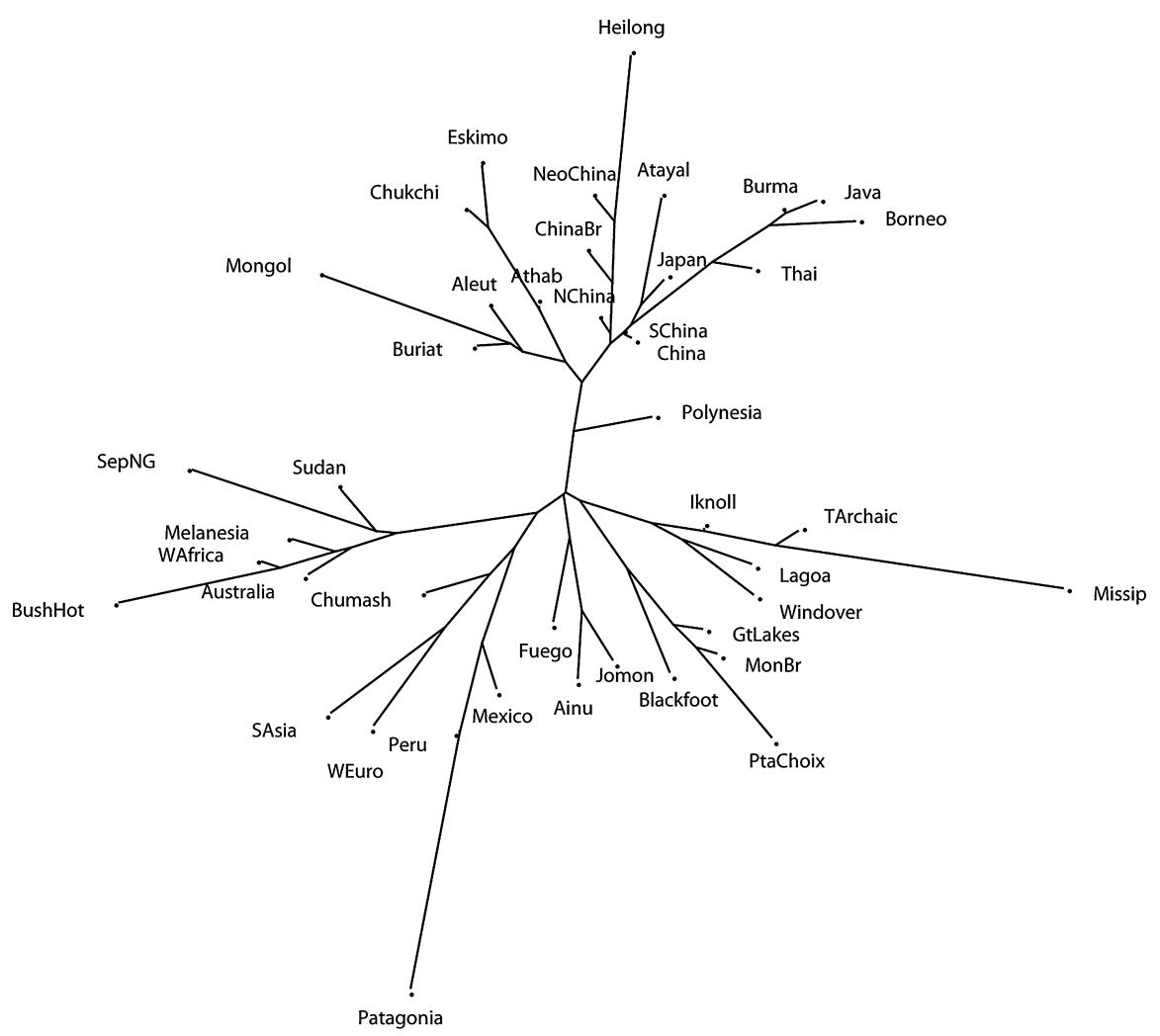

Figure 8. The neighbor-joining tree using 21 variables with all reference samples. 
Table 3. The biological distances generated by R-matrix (using 19 variables)

\begin{tabular}{|c|c|c|c|c|c|c|}
\hline & Lagoa & Jōmon & Australia & Melanesia & Indian knoll & Tennessee archaic \\
\hline Jōmon & 4.58 & 0.00 & 11.74 & 13.68 & 12.24 & 7.68 \\
\hline Ainu & 9.00 & 4.16 & 13.71 & 13.78 & 16.29 & 16.00 \\
\hline Atayal & 7.33 & 15.20 & 13.12 & 13.24 & 11.03 & 16.49 \\
\hline Japan & 8.74 & 15.45 & 12.54 & 12.35 & 5.77 & 11.08 \\
\hline North China & 12.98 & 17.67 & 15.57 & 17.23 & 9.37 & 12.63 \\
\hline South China & 12.63 & 17.22 & 13.45 & 13.67 & 10.09 & 14.96 \\
\hline China & 13.51 & 18.25 & 14.11 & 14.40 & 10.83 & 15.24 \\
\hline Neolithic China & 19.59 & 18.76 & 20.76 & 22.26 & 15.91 & 19.84 \\
\hline Heilong & 25.47 & 21.93 & 27.41 & 30.61 & 22.20 & 21.96 \\
\hline Mongol & 21.92 & 20.24 & 17.59 & 21.51 & 15.85 & 13.39 \\
\hline Thai & 9.21 & 15.12 & 8.18 & 7.41 & 8.39 & 12.72 \\
\hline Burma & 12.51 & 17.13 & 9.15 & 10.38 & 12.35 & 15.17 \\
\hline Borneo & 16.64 & 16.78 & 12.14 & 11.49 & 17.21 & 20.61 \\
\hline Java & 16.04 & 19.84 & 14.05 & 14.33 & 13.46 & 16.52 \\
\hline China Bronze Age & 11.28 & 13.57 & 12.32 & 14.43 & 9.40 & 13.08 \\
\hline Patagonia & 16.42 & 16.23 & 23.09 & 25.49 & 18.54 & 22.61 \\
\hline West Europe & 8.03 & 14.25 & 15.02 & 18.35 & 11.46 & 11.91 \\
\hline Mongol Bronze Age & 13.82 & 13.08 & 10.69 & 15.47 & 8.38 & 4.90 \\
\hline Chukchi & 17.99 & 16.66 & 18.36 & 18.21 & 19.20 & 18.17 \\
\hline Buriat & 13.37 & 14.04 & 13.57 & 13.30 & 11.73 & 13.59 \\
\hline Australia & 11.08 & 11.74 & 0.00 & 3.55 & 12.40 & 12.00 \\
\hline West Africa & 12.79 & 16.62 & 5.53 & 4.02 & 16.70 & 21.89 \\
\hline Sudan & 10.56 & 14.82 & 6.24 & 5.01 & 16.10 & 20.16 \\
\hline Bushman/Hottentot & 16.07 & 22.73 & 9.46 & 8.18 & 18.67 & 24.32 \\
\hline Lagoa & 0.00 & 4.58 & 11.08 & 9.28 & 2.34 & 4.93 \\
\hline Chumash & 7.86 & 11.74 & 10.23 & 10.44 & 10.08 & 12.39 \\
\hline Fuego & 4.94 & 5.95 & 10.71 & 12.24 & 10.12 & 9.25 \\
\hline Peru & 7.56 & 12.02 & 14.60 & 15.15 & 12.39 & 15.02 \\
\hline Mexico & 5.31 & 8.89 & 8.18 & 10.21 & 9.32 & 12.23 \\
\hline Blackfoot & 14.42 & 16.84 & 15.59 & 20.13 & 14.49 & 12.71 \\
\hline Great Lakes & 13.01 & 12.86 & 8.41 & 16.36 & 9.77 & 5.78 \\
\hline Missip & 15.92 & 21.67 & 17.18 & 24.26 & 7.62 & 6.65 \\
\hline Windover & 5.92 & 11.88 & 9.81 & 12.61 & 5.94 & 3.76 \\
\hline Port au Choix & 14.66 & 14.45 & 13.36 & 18.00 & 12.88 & 6.39 \\
\hline Athab & 9.75 & 11.40 & 13.54 & 10.91 & 9.22 & 10.71 \\
\hline Eskimo & 17.20 & 13.00 & 21.59 & 22.73 & 16.86 & 16.83 \\
\hline Aleut & 13.37 & 12.80 & 14.63 & 12.09 & 12.85 & 14.43 \\
\hline Tennesse archaic & 4.93 & 7.68 & 12.00 & 16.92 & 2.94 & 0.00 \\
\hline Indian Knoll & 2.34 & 12.24 & 12.40 & 14.04 & 0.00 & 2.94 \\
\hline South Asia & 9.95 & 17.33 & 10.58 & 13.58 & 11.48 & 15.34 \\
\hline Papua New Guinea & 19.22 & 24.98 & 8.88 & 6.71 & 20.34 & 28.38 \\
\hline Melanesia & 9.28 & 13.68 & 3.55 & 0.00 & 14.04 & 16.92 \\
\hline Polynesia & 9.83 & 9.63 & 9.33 & 12.71 & 9.62 & 10.58 \\
\hline
\end{tabular}

morphology in South and North America (Neves et al., 1998, 2003, 2005; Neves and Pucciarelli, 1998; Powell and Neves, 1999; González et al., 2003; González-José et al., 2005; Neves and Hubbe, 2005; Seguchi et al., 2005, 2006).

Now, how can we interpret the morphological divergence of Paleoamericans and Archaic Americans, and Early Holocene populations of East Asia? Table 5 and Table 6 present the results of a Relethford-Blangero analysis on archaic Americans and ancient East Asians, with Lagoa Santa added. Because computation of the R-matrix method requires census population sizes of samples, it should adopt relative population weight (Hanihara et al., 2008). We computed relative weights of the effective population size of 1.0 for all archaic samples, Neolithic Chinese, Bronze Age Chinese and the Jomon, then we repeated computation using an $N e$ of 0.30 for Lagoa Santa. We followed this estimate of relative size used in the study by Powell and Neves (1999), which was derived using the upper end of the early Holocene census population size of Paleoamericans of North America from Steele and Powell (1998) relative to estimates of late Holocene census size in North America (Ubelaker, 1992). Unfortunately we violate the synchronic nature of the Rmatrix by including samples from a greater time depth, such as over 4000 years, due to the lack of samples (Hanihara, 2010). The ancient East Asian samples exhibit positive residual value deviations except the Bronze Age Chinese, while the New World samples show negative residual values when 21 variables are used (not shown). When 19 variables are used, only the Windover sample displays positive residual values, but they are very small $(0.0005)$; however, the $P$-value is not significant (Table 5). When we apply an $\mathrm{Ne}$ of 0.30 for Paleoamericans, the Windover sample shows negative residual values, and all the New World samples, including Lagoa Santa, show negative residual values as well. The Jomon and Lagoa Santa were plotted nearby in the principal coordinate plots when we weighted 0.30 for Lagoa 
Table 4. Squared Mahalanobis distances and typicality probabilities (tp) of each cranium of Lagoa Santa

\begin{tabular}{|c|c|c|}
\hline & D squared & tp (F-distribution) \\
\hline \multicolumn{3}{|l|}{ Sumid 3} \\
\hline Tennesse archaic & 14.910 & 0.765 \\
\hline Jōmon & 15.892 & 0.704 \\
\hline Windover & 16.799 & 0.645 \\
\hline Port au Choix & 18.352 & 0.572 \\
\hline Indian Knoll & 19.602 & 0.457 \\
\hline Melanesia* & 23.207 & 0.252 \\
\hline Australia* & 25.428 & 0.171 \\
\hline \multicolumn{3}{|l|}{ Sumid 4} \\
\hline Indian Knoll & 16.955 & 0.628 \\
\hline Jōmon & 19.096 & 0.498 \\
\hline Tennessee archaic & 19.145 & 0.498 \\
\hline Fuego & 21.040 & 0.396 \\
\hline Windover & 21.965 & 0.330 \\
\hline Melanesia* & 29.656 & 0.067 \\
\hline Australia* & 34.094 & 0.024 \\
\hline \multicolumn{3}{|l|}{ Sumid 9} \\
\hline Atayal & 17.164 & 0.618 \\
\hline Melanesia & 17.177 & 0.603 \\
\hline Jōmon & 18.028 & 0.567 \\
\hline Burma & 18.119 & 0.556 \\
\hline Windover & 19.307 & 0.484 \\
\hline Australia* & 19.695 & 0.448 \\
\hline \multicolumn{3}{|l|}{ Sumid 16} \\
\hline Mexico & 14.478 & 0.790 \\
\hline Atayal & 16.487 & 0.662 \\
\hline Indian Knoll & 16.589 & 0.652 \\
\hline Fuego & 16.649 & 0.669 \\
\hline Peru & 16.903 & 0.625 \\
\hline Jōmon* & 17.483 & 0.602 \\
\hline Australia* & 22.604 & 0.286 \\
\hline Melanesia* & 23.716 & 0.230 \\
\hline \multicolumn{3}{|l|}{ Lund 5227} \\
\hline Indian Knoll & 16.785 & 0.639 \\
\hline West Europe & 18.872 & 0.479 \\
\hline Chumash & 19.298 & 0.469 \\
\hline Mexico & 19.424 & 0.482 \\
\hline Blackfoot & 20.009 & 0.440 \\
\hline Melanesia* & 25.756 & 0.155 \\
\hline Jōmon* & 27.699 & 0.114 \\
\hline Australia* & 29.709 & 0.069 \\
\hline
\end{tabular}

Nearest reference samples are shown for each specimen.

* Comparative samples, such as Australia, Melanesia, and Jōmon
Santa (see Figure 9, Figure 10). These results indicate that the ancient East Asians have more than expected craniofacial variations (also see Ishida et al., 2009), but the New World populations show less than expected craniofacial variations (Table 5, Table 6). It appears that New World samples are more newly derived populations than are ancient East Asian populations.

\section{Conclusions}

Our results show that Lagoa Santa individuals exhibit stronger morphological affinities with the Indian Knoll, Tennessee, and Windover archaic of North America and the prehistoric Jōmon of Japan, than with our Melanesian and Australian samples. The relationships shared with Lagoa Santa and Melanesians are exhibited in Sumidoro 9. However, this skull displays similarity with the Atayal of Taiwan, and the probabilities and Mahalanobis distances between Melanesians and Sumidoro 9, and between the Jomon and Sumidoro 9, are very close to each other. This can be explained by all populations having individuals that overlap the distributions of virtually any other population, but it does not necessarily signify a genetic relationship. R-matrix analysis indicates that Lagoa Santa exhibits more similarity to Jōmon than Australia. All these suggest that the early inhabitants of South America were probably not directly related to Australo-Melanesians, but rather to the Late Pleistocene inhabitants of Northeast Asia, such as an ancestor of the Jomon. Also, they are related to the Archaic North American populations and recent Central and South Americans.

From our analysis, by using a battery of craniofacial measurements, we can see linkages running all the way from northern Europe, both prehistoric and modern, across via Mongolia to coastal Northeast Asia, and southeastwards out into the Pacific, and over into the representatives of at least one of the main components of the native peoples of the New World. It had already been shown that the Jomon inhabitants of prehistoric Japan were not only the obvious ancestors of the living Ainu but also had to have been a major source for one of the principal components of the preColumbian inhabitants of the New World. This study does not support affinities between the Early Brazilians and Australians and Melanesians. Neves et al. (2003, 2005, 2007) and Neves and Hubbe (2005), on the other hand, have

Table 5. Relethford-Blangero analysis of 19 variables: genetic distances to the centroid and observed, expected, and residual variances for early Holocene East Asia and New World populations

\begin{tabular}{|c|c|c|c|c|c|c|c|c|}
\hline Region & $W$ ei & Rii & Obs-var & Exp-var & Residual & SE & $t(d f=18)$ & $P$ \\
\hline Jōmon & 1.00 & 0.2065 & 1.0867 & 0.7996 & 0.2871 & 0.1012 & 2.8367 & 0.0109 \\
\hline Neolithic China & 1.00 & 0.3725 & 0.8943 & 0.6323 & 0.2620 & 0.1031 & 2.5410 & 0.0205 \\
\hline China Bronze Age & 1.00 & 0.1737 & 0.7562 & 0.8326 & -0.0764 & 0.0535 & 1.4291 & 0.1701 \\
\hline Mongol Bronze Age & 1.00 & 0.2308 & 0.9262 & 0.7750 & 0.1512 & 0.1023 & 1.4774 & 0.1569 \\
\hline Lagoa & 1.00 & 0.1143 & 0.7126 & 0.8925 & -0.1798 & 0.1610 & 1.1173 & 0.2786 \\
\hline Windover & 1.00 & 0.1455 & 0.8615 & 0.8610 & 0.0005 & 0.0618 & 0.0081 & 0.9936 \\
\hline Port au Choix & 1.00 & 0.2429 & 0.5745 & 0.7629 & -0.1884 & 0.0960 & 1.9621 & 0.0654 \\
\hline Tennesse archaic & 1.00 & 0.0651 & 0.7969 & 0.9420 & -0.1451 & 0.0741 & 1.9594 & 0.0657 \\
\hline Indian Knoll & 1.00 & 0.0872 & 0.5840 & 0.9198 & -0.3357 & 0.0519 & 6.4718 & 0.0000 \\
\hline
\end{tabular}

All samples are weighted equally by 1.0

Region no. $=9, h^{2}=0.55, F$ st $=0.2068, \mathrm{Vgw}=0.7992$

Sum of squared residuals $=0.38137$. 
Table 6. Relethford-Blangero analysis of 19 variables: genetic distances to the centroid and observed, expected, and residual variances for early Holocene East Asia and New World populations

\begin{tabular}{|c|c|c|c|c|c|c|c|c|}
\hline Region & $W$ ei & $R$ ii & Obs-var & Exp-var & Residual & SE & $t(d f=18)$ & $P$ \\
\hline Jōmon & 1.00 & 0.2096 & 1.0867 & 0.7958 & 0.2909 & 0.0958 & 3.0356 & 0.0071 \\
\hline Neolithic China & 1.00 & 0.3382 & 0.8943 & 0.6664 & 0.2279 & 0.0999 & 2.2822 & 0.0349 \\
\hline China Bronze Age & 1.00 & 0.1652 & 0.7562 & 0.8405 & -0.0843 & 0.0522 & 1.6141 & 0.1239 \\
\hline Mongol Bronze Age & 1.00 & 0.2093 & 0.9262 & 0.7961 & 0.1300 & 0.0933 & 1.3941 & 0.1803 \\
\hline Lagoa & 0.30 & 0.1471 & 0.7126 & 0.8587 & -0.1461 & 0.1795 & 0.8137 & 0.4265 \\
\hline Windover & 1.00 & 0.1407 & 0.8615 & 0.8651 & -0.0036 & 0.0573 & 0.0628 & 0.9506 \\
\hline Port au Choix & 1.00 & 0.2287 & 0.5745 & 0.7766 & -0.2021 & 0.0859 & 2.3514 & 0.0303 \\
\hline Tennesse archaic & 1.00 & 0.0625 & 0.7969 & 0.9439 & -0.1470 & 0.0685 & 2.1459 & 0.0458 \\
\hline Indian Knoll & 1.00 & 0.0999 & 0.5840 & 0.9063 & -0.3222 & 0.0571 & 5.6469 & 0.0000 \\
\hline
\end{tabular}

Lagoa Santa is weighted by 0.30 .

Region no. $=9, h^{2}=0.55, F \mathrm{st}=0.1990, \mathrm{Vgw}=0.8065$.

Sum of squared residuals $=0.34823$.

Scaled Eigenvectors(unbiased) $h^{2}=0.55 ; F_{s t}=0.201 ; E V 1$, EV2, EV3 $=43.2,24.0,16.9(\%)$
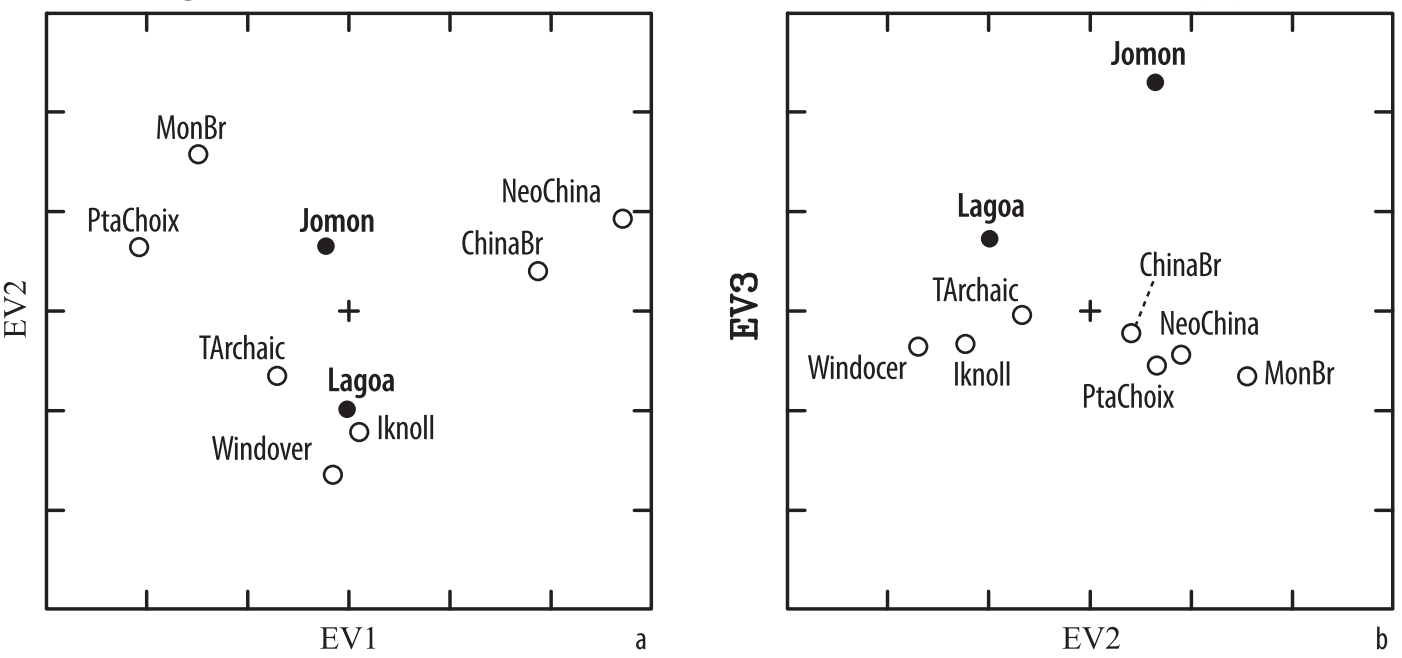

$\begin{array}{lc} & \text { Weight } \\ \text { Jomon } & 1 \\ \text { NeoChina } & 1 \\ \text { ChinaBr } & 1 \\ \text { MonBr } & 1 \\ \text { Lagoa } & 1 \\ \text { Windover } & 1 \\ \text { PtaChoix } & 1 \\ \text { TArchaic } & 1 \\ \text { Iknoll } & 1\end{array}$

Figure 9. Principal coordinate plot using 19 variables of Early and Late Holocene New World populations. R-matrix analysis using relative weights of 1.0 for all samples.

failed to include a prehistoric Northeast Asian population in their data and denied that Lagoa Santa shares similar craniofacial characteristics found in archaic North American populations. However, our analysis is based on only five Lagoa Santa individuals. Further research with more early specimens from Brazilian Paleoamerican is necessary. Also, both our analysis and that of Neves et al. (2003, 2005, 2007) and Neves and Hubbe (2005) do not include the samples of the Late Pleistocene/Early Holocene Australians. A comparison between the Early South Americans and the Early Australians, such as the Coobool Crossing of the Wakool River and Kohuna, is necessary for future analysis.

Furthermore, studies of the peopling of the New World can provide many interesting questions and models for human population history. Since some migration involves crossing from an extremely cold, harsh environment to a tropical environment, while others involve moving to a cold environment again, further studies should be focused on human dispersal and related biological adaptations (Hall et al., 2004). For example, if the ancient Australians migrated from tropical South Asia to Arctic cold Northeast Asia and across Beringia, the question is whether or not selections for cold adaptations occurred during human migrations. Moreover, it is important to see whether selection of heat adaptation occurred again when ancient peoples moved into the tropical areas of South America. How long does it take to 
Scaled Eigenvectors(unbiased) $h^{2}=0.55 ; F_{s t}=0.199 ; E V 1, E V 2, E V 3=47.0,20.5,16.9(\%)$
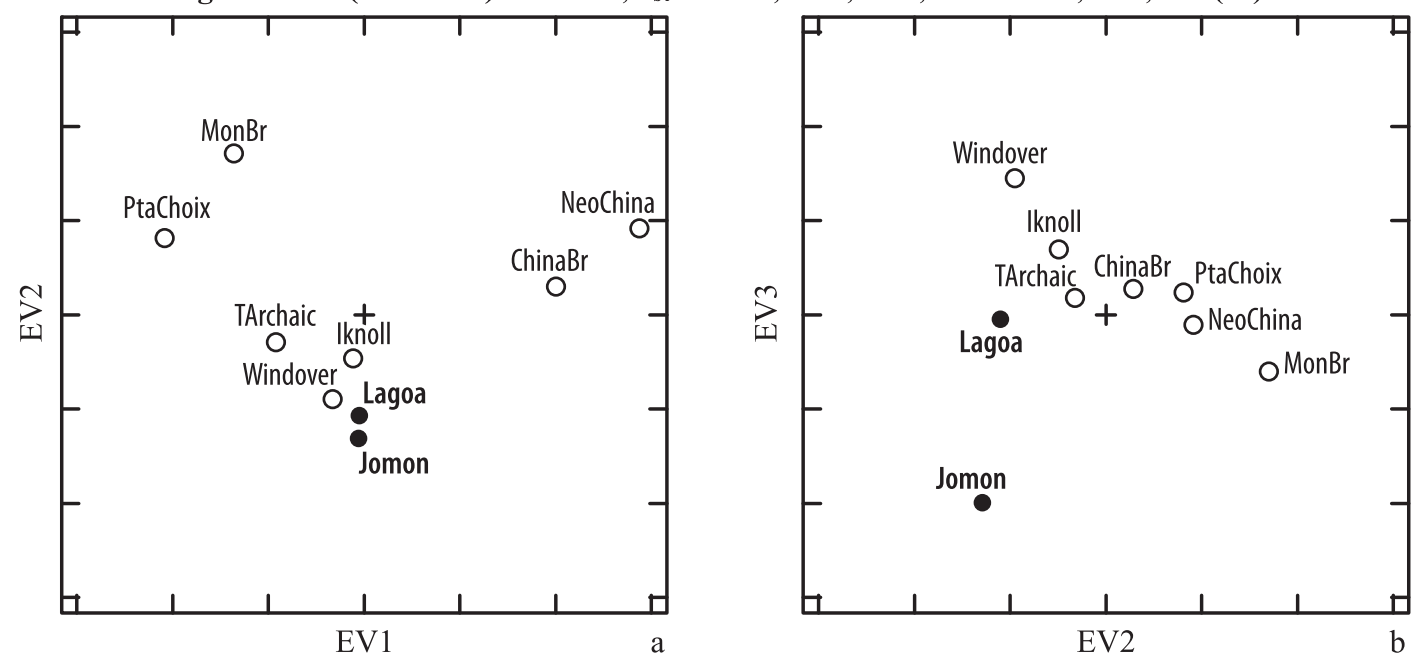

$\begin{array}{lc} & \text { Weight } \\ \text { A: Jomon } & 1 \\ \text { B: NeoChina } & 1 \\ \text { C: ChinaBr } & 1 \\ \text { D: MonBr } & 1 \\ \text { E: Lagoa } & \mathbf{0 . 3} \\ \text { F: Windover } & \mathbf{1} \\ \text { G: PtaChoix } & 1 \\ \text { H: TArchaic } & 1 \\ \text { I: Iknoll } & 1\end{array}$

Figure 10. Principal coordinate plot using 19 variables of Early and Late Holocene New World populations. R-matrix analysis using relative weights of 1.0 for all samples, but an Ne of 0.30 for Paleoamerican, Lagoa Santa.

change morphology by adaptations to different climatic regimes? Did genetic drift take place instead of selection? Or did genetic drift and selection interact? There are many challenging questions in the study of the peopling of the New World. This study only deals with craniometric views on the peopling of South America. Furthermore, not only craniofacial analysis, but also odontometric analysis and postcranial studies that relate to adaptation and dispersal should be done in order to test population affinities of the Early Paleoamericans in Brazil.

\section{Acknowledgments}

We would like to thank Professor T. Hanihara (the editorin-chief) of the Department of Anatomy, Kitasato University School of Medicine, Professor H. Ishida of Department of Anatomy, Faculty of Medicine, University of the Ryukyus, and two anonymous reviewers for their helpful comments. We also would like to thank Dr T. Fukumine, Department of Anatomy, Faculty of Medicine, University of the Ryukyus for help in the illustration of figures. For access to the material used in the work reported here we are grateful to the curators and managers of the collections in: The Academia Sinica in Taipei, Taiwan; University of Alabama Museums, Moundville, AL, USA, Department of Anthropology; The American Museum of Natural History, Division of Anthropology, New York, NY, USA; The Anyang Museum, Henan, the People's Republic of China; The Ban Po Museum in Xian, People's Republic of China; The Bernice
P. Bishop Museum, Honolulu, HI, USA; The Burke Memorial Museum, University of Washington, Seattle, WA, USA; Central Washington University, Ellensburg, Washington, DC, USA, Department of Anthropology; The College of Traditional Chinese Medicine in Chengdu, People's Republic of China; The Dickson Mounds Museum, Lewistown, IL, USA; The Duckworth Laboratory, Cambridge University, Cambridge, UK; Erindale College, Mississagua, Ontario, Canada; Fudan University, Department of Biology, Shanghai, People's Republic of China; Gadja Mada University, Laboratory of Physical Anthropology, Yogyakarta, Indonesia; The Field Museum, Department of Anthropology, Chicago, IL, USA; The Fowler Museum, University of California Los Angeles, Los Angeles, CA, USA; The Indiana University Laboratory of Bioanthropology, Bloomington, IN, USA; The Hearst Gymnasium Basement and the Lowie Museum, University of California Berkeley, Berkelely, CA, USA; The Illinois State Museum, Springfield, IL, USA; Laboratory of Bioanthropology, Indiana University, Bloomington, IN, USA; The Institute of Archaeology in the Chinese Academy of Social Sciences in Beijing, and the Institute of Vertebrate Paleontology and Paleoanthropology, Beijing, People's Republic of China; The Institute of Archaeology, Mongolian Academy of Sciences, Ulaanbaatar, Mongolia; The Institute of Zoology, Copenhagen, Denmark; Istituto di Antropologia, Florence, Italy; The Kyoto University Laboratory of Physical Anthropology, Kyoto, Japan; The Kyushu University Medical School, Department of Human Anatomy, Fukuoka, Japan; 
McClung Museum, University of Tennessee, Knoxville, TN, USA; Memorial University, St Johns, Newfoundland, Canada; Musée de l'Homme, Paris, France; The Museum of Anthropology, University of Michigan, Ann Arbor, MI, USA; The Museum of Anthropology, Tokyo University, Tokyo, Japan; The Nagasaki University Medical School, Department of Anatomy, Nagasaki, Japan; The Nanning Medical College, Guangxi-Zhuang Autonomous Region, People's Republic of China; The Natural History Museum, London, UK; Nevada State Museum, Carson City, NV, USA; The Ohio State Museum, Ohio Historical Society, Columbus, OH, USA; The Peabody Museum of Archaeology and Ethnology, Harvard University, Cambridge, MA, USA; University of Porto Laboratory of Anthropology, Porto, Portugal; The Prince Philip Dental Hospital, Hong Kong; The Rochester Museum \& Science Center, Rochester, NY, USA; The Sapporo Medical College, Department of Anatomy II, Sapporo, Japan; The Sirirai Hospital, Bangkok, Thailand; The Smithsonian Institution, National Museum of Natural History, Department of Anthropology, Washington, DC, USA; The William S. Webb Museum of Anthropology, University of Kentucky, Titusville, KY, USA; and the Windover Laboratory, Titusville, FL, USA.

\section{References}

Albrecht G.H. (1992) Assessing the affinities of fossils using canonical variates and generalized distances. Human Evolution, 7: 49-69.

Allard F. and Erdenebaatar D. (2005) Khirigsuurs, ritural and mobility in the Bronze Age of Mongolia. Antiquity, 79: 547-563.

Anderson J.E. (1976) The human skeletons. In: Tuck J.A. (ed.), Ancient People of Port au Choix: The Excavation of an Archaic Indian Cemetery in Newfoundland, Social Economic Studies No. 17. Newfoundland, St Johns, pp. 124-131.

Betti L., Balloux F., Hanihara T., and Manica A. (2010) The relative role of drift and selection in shaping the human skull. American Journal of Physical Anthropology, 141: 76-82.

Boas F. (1912) Changes in the bodily form of descendants of immigrants. Columbia University Press, New York.

Brace C.L. (2005) 'Neutral theory' and the dynamics of the evolution of 'modern' human morphology. Human Evolution, 19: $19-38$.

Brace C.L. and Hunt K.D. (1990) A nonracial craniofacial perspective on human variation: A(ustralia) to Z(uni). American Journal of Physical Anthropology, 82: 341-360.

Brace C.L. and Tracer D.P. (1992) Craniofacial continuity and change: a comparison of Late Pleistocene and Recent Europe and Asia. In: Akazawa T., Aoki K., and Kimura T. (eds.), The Evolution and Dispersion of Modern Humans in Asia. Hokusen-Sha, Tokyo, pp. 439-471.

Brace C.L., Nelson A.R., Seguchi N., Oe H., Sering L., Pan Q., Li Y., and Tumen D. (2001) Old World sources of the first New World human inhabitants: a comparative craniofacial view. Proceedings of the National Academy of Sciences of the United States of America, 98: 10017-10022.

Brace C.L., Seguchi N., Quintyn C.B., Fox S.C., Nelson A.R., Manolis S.K., and Qifeng P. (2006) The questionable contribution of the Neolithic and the Bronze Age to European craniofacial forms. Proceedings of the National Academy of Sciences of the United States of America, 102: 242-247.

Brace C.L., Seguchi N., and Brace M.L. (2008) Exploring the Kennewick connection. In: Smith C., Zimmerman L., Watkins J., and Ippert D. (eds.), Kennewick Man: Perspectives on the Ancient One. The Left Coast Press in Australia, Walnut Creek, pp. 153-168.
Brown P. (1999) The first modern East Asians? Another look at Upper Cave 101, Liujiang and Minatogawa 1. In: Omoto K. (ed.), Interdisciplinary Perspectives on the Origins of the Japanese. International Research Center for Japanese Studies, Kyoto, pp. 105-130.

Carlson D.S. and Van Gerven D.P. (1977) Masticatory function and post-Pleistocene evolution in Nubia. American Journal of Physical Anthropology, 46: 495-506.

Carson E.A. (2006) Maximum likelihood estimation of human craniometric heritabilities. American Journal of Physical Anthropology, 131: 169-180.

Devor E.J. (1987) Transmission of human craniofacial dimensions. Journal of Craniofacial Genetics and Developmental Biology, 7: 95-106.

Doran G.H. (2002) Windover: Multidisciplinary Investigations of an Early Archaic Florida Cemetery. University Press of Florida, Gainesville.

Goebel T. (1999) Pleistocene human colonization of Siberia and peopling of the Americas: an ecological approach. Evolutionary Anthropology, 8: 208-227.

González S., Concepción J., López J., Hedges J., Huddart D., Ohman J.C., Turner A., and Padilla J.A.P. (2003) Earlest humans in the Americas: new evidence from México. Journal of Human Evolution, 44: 379-387.

González-José R., Van der Molen S., González-Pérez E., and Hernández M. (2004) Patterns of phenotypic covariation and correlation in modern humans as viewed from morphological integration. American Journal of Physical Anthropology, 123: 69-77.

González-José R., Neves W., Lahr M.M., Gonzáles S., Pucciarelli H., Martinez M.H., and Correal G. (2005) Late Pleistocene/ Holocene craniofacial morphology in Mesoamerican Paleoamericans: implications for the peopling of the New World. American Journal of Physical Anthropology, 128: 772-780.

Hall R., Roy D., and Boling D. (2004) Pleistocene migration routes into the Americas: human biological adaptations and environmental constraints. Evolutionary Anthropology, 13: $132-144$.

Hanihara T. (2010) Metric and non metric dental variation and the population structure of the Ainu. American Journal of Human Biology, 22: 163-171.

Hanihara T. and Ishida H. (2005) Metric dental variation of major human populations. American Journal of Physical Anthropology, 128: 287-298.

Hanihara T. and Ishida H. (2009) Regional differences in craniofacial diversity and population history of Jomon Japan. American Journal of Physical Anthropology, 139: 311-322.

Hanihara T., Yoshida K., and Ishida H. (2008) Craniometric variation of the Ainu: an assessment of differential gene flow from Northeast Asia into northern Japan, Hokkaido. American Journal of Physical Anthropology, 137: 283-293.

Harpending H.C. and Jenkins T. (1973) Genetic distance among Southern African populations. In: Crawford M.H. and Workman P.L. (eds.), Methods and Theories of Anthropological Genetics. University of New Mexico Press, Albuquerque, pp. $177-199$.

Harvati K. and Weaver T.D. (2006) Human cranial anatomy and the differential preservation of population history and climate signatures. Anatomical Record, 288A: 1225-1233.

Howells W.W. (1973) Cranial variation in man: a study by multivariate analysis of patterns of difference among recent human populations. Papers of the Peabody Museum of Archaeology and Ethnology, Vol. 67. Harvard University Press, Cambridge, MA.

Hubbe M., Hanihara T., and Havati K. (2009) Climate signatures in the morphological differentiation of worldwide modern human populations. Anatomical Record, 292: 1720-1733.

Huson D.H. and Bryant D. (2006) Application of phylogenetic networks in evolutionary studies. Molecular Biology and Evolution, 23: 254-267. 
Ishida H., Hanihara T., Kondo O., and Fukumine T. (2009) Craniometric divergence history of the Japanese populations. Anthropological Science, 117: 147-156.

Jantz R.L. (2000) Cranial change in Americans: 1850-1975. Journal of Forensic Science, 46: 784-787.

Jantz R.L. and Meadows L. (2000) Secular change in craniofacial morphology. American Journal of Human Biology, 12: 327 338.

Jantz R.L. and Owsley D.W. (2001) Variation among early North American crania. American Journal of Physical Anthropology, 114: 146-155.

Jantz R.L. and Owsley D.W. (2003) Reply to Van Vark et al.: Is European Upper Paleolithic cranial morphology a useful analogy for Paleoamericans? American Journal of Physical Anthropology, 121: 185-188.

Jantz R.L. and Owsley D.W. (2006) Circumpacific populations and the peopling of the New World: evidence from cranial morphometrics. In: Bonnichsen R., Lepper T., Stanford D., and Waters M.R. (eds.), Paleoamerican Origins: Beyond Clovis. Texas A\&M University Press, College Station, pp. 267-275.

Kamminga J. and Wright R.V.S. (1988) The Upper Cave at Zhoukoudian and the origins of the Mongoloids. Journal of Human Evolution, 17: 738-767.

Karafet T.M., Zegura S.L., Posukh O., Osipova L., Bergen A., Long L., Goldman D., Klitz W., Harihara S., de Knijff P., Wiebe V., Griffiths R.C., Templeton A.R., and Hammer M.F. (1999) Ancestral Asian source(s) of New World chromosome founder haplotypes. American Journal of Human Genetics, 64: 817-831.

Kimura M. (1968) Evolutionary rate at the molecular level. Nature, 217: 624-626.

Kouchi M. (2000) Brachycephalization in Japan has ceased. American Journal of Physical Anthropology, 112: 339-347.

Lahr M.M. (1992) The origins of modern humans: a test of the multiregional hypothesis. Ph.D. dissertation, University of Cambridge, Cambridge.

Lahr M.M. (1995) Patterns of modern human diversification: implications for Amerindian origins. Yearbook of Physical Anthropology, 38: 163-198.

Lahr M.M. (1996) The Evolution of Modern Human Diversity: A Study of Cranial Variation. Cambridge University Press, Cambridge.

Lahr M.M. and Wright R.V.S. (1996) The question of robusticity and the relationship between cranial size and shape in Homo sapiens. Journal of Human Evolution, 31: 157-191.

Martin R. (1928) Lehrbuch der Anthropologie. Aufl. G. Fishcher, Jena.

Mizoguchi Y. (2000) Still-unknown determinants of the cranial shape. Acta Anatomica Nipponica, 75: 197-206 (in Japanese).

Necrasov O. (1974) Le processus de brachecéphalisation dan les populations de Roumanie à partir du Neolithiques et jusqu'à nos jours. Bevölkerungsbiologie. Gustav Fischer, Stuttgart, pp. 512-524.

Nelson A.R. (2006) Patterns of craniometric variation and geographical distribution in North America: a historical comparison. In: Bonnichsen R., Lepper T., Stanford D., and Waters M.R. (eds.), Paleoamerican Origins: Beyond Clovis. Texas A\&M University Press, College Station, pp. 277-288.

Nelson A.R., Seguchi N., and Brace C.L. (2007) Craniofacial form and regional population affinities: a comparative approach to Paleo-Indian origins. In: Ubelaker D. (ed.), Environment, Origins, and Population, Handbook of North American Indians Series, Vol. 3. Smithsonian Institution, Washington DC, pp. 679-684

Neves W.A. and Hubbe M. (2005) Cranial morphology of Paleoamericans from Lagoa Santa: implications for the settlement of the New World. Proceedings of the National Academy of Sciences of the United States of America, 102: 18309-18314.

Neves W.A. and Pucciarelli H.M. (1991) Morphological affinities of the first Americans: an exploratory analysis based on early South American human remains. Journal of Human Evolution, 21: 261-273.

Neves W.A. and Pucciarelli H.M. (1998) The Zhoukoudian upper cave skull 101 as seen from the Americas. Journal of Human Evolution, 34: 219-222.

Neves W.A., Prous A., Powell J.F., and Ozolins E.G. (1998) Lapa Vermelha IV Hominid 1: Morphological affinities of the earliest known American. American Journal of Physical Anthropology, Supplement 26: 169.

Neves W.A., Powell J.F., and Ozolins E.G. (1999) Modern human origins as seen from the peripheries. Journal of Human Evolution, 37: 129-133.

Neves W.A., Prous A., González-José R., Kipnis R., and Powell J. (2003) Human skeletal remains from Santana de Riacho, Brazil: implications for the settlement of the New World. Journal of Human Evolution, 45: 759-782.

Neves W.A., Hubbe M., Mercedes M., Okumura M., GonzálezJosé R., Figuti L., Eggers S., and De Blasis P.A.D. (2005) A new early Holocene human skeleton from Brazil: implications for the settlement of the New World. Journal of Human Evolution, 48: 403-414.

Neves W.A., Hubbe M., and Pilo L.B. (2007) Early Holocene human remains from Sumidouro cave, Lagoa Santa, Brazil: history of discoveries, geological and chronological context, and comparative cranial morphology. Journal of Human Evolution, 52: 16-30.

Ohta T. and Kimura M. (1971) On the constancy of the evolutionary rate of cistrons. Journal of Molecular Evolution, 1: 18-25.

Okazaki K. (2004) A morphological study on the growth patterns of ancient people in the northern Kyushu-Yamaguchi region, Japan. Anthropological Science, 112: 219-234.

Perzigian A.J. (1976) The dentition of the Indian Knoll skeletal population: Odontometrics and cusp number. American Journal of Physical Anthropology, 44: 113-121.

Powell J.F. and Neves W.A. (1999) Craniofacial morphology of the first Americans: pattern and process in the peopling of the New World. Yearbook of Physical Anthropology, 42: 153188.

Powell J.F. and Rose J.C. (1999) Report on the osteological assessment of the 'Kennewick Man' skeleton (CENWW97. Kennewick). Report on the Non-destructive Examination, Description, and Analysis of Human Remains from Columbia Park, Kennewick, Washington (October 1999). National Park Service, Washington DC, http://www.cr.nps.gov/aad/ kennewick/

Raghunathan T.E., Solenberger P.W., and Van Hoewyk J. (2004) IVEware: imputation and variance estimation software. Survey Methodology Program Survey Research Center, Institute for Social Research, University of Michigan, Ann Abor.

Relethford J.H. (1991) Genetic drift and anthropometric variation in Ireland. Human Biology, 63: 155-165.

Relethford J.H. (1994) Craniometric variation among modern human populations. American Journal of Physical Anthropology, 95: 53-62.

Relethford J.H. (2002) Apportionment of global human genetic diversity based on craniometrics and skin color. American Journal of Physical Anthropology, 118: 393-398.

Relethford J.H. (2004) Boas and beyond: migration and craniometric variation. American Journal of Human Biology, 16: 379386.

Relethford J.H. (2007) The use of quantitative traits in anthropological genetic studies of population structure and history. In: Crawford M. (ed.), Anthropological Genetics Theory, Methods and Applications. The Cambridge University Press, Cambridge, pp. 187-209.

Relthford J.H. and Blangero J. (1990) Detection of differential gene flow from patterns of quantitative variation. Human Biology, 62: 5-25.

Relethford J.H. and Harpending H.C. (1994) Craniometric varia- 
tion, genetic theory, and modern human origins. American Journal of Physical Anthropology, 95: 249-270.

Relethford J.H. and Harpending H.C. (1995) Ancient differences in population size can mimic a recent African origin and modern humans. Current Anthropology, 36: 667-674.

Relethford J.H., Crawford M.H., and Blangero J. (1997) Genetic drift and gene-flow in post famine Ireland. Human Biology, 69: 443-465.

Rivet P. (1908) La race de Lagôa Santa chez les populations précolombiennes de l'Équateure. Bulletins et Mémoires de la Société d'anthropologie de Paris, 5e série, t. IX, Paris, pp. 209-268.

Rivet P. (1957) Les origines de l'homme Americain. Gallimard, Paris.

Roseman C.C. (2004) Detecting interregionally diversifying natural selection on modern human cranial form by using matched molecular and morphometric data. Proceedings of the National Academy of Sciences of the United States of America, 101: 12824-12829.

Roseman C.C. and Weaver T.D. (2004) Multivariate apportionment of global human craniometric diversity. American Journal of Physical Anthropology, 125: 257-263.

Saitou N. and Nei M. (1987) The neighbor-joining method: a new method for reconstructing phylogenetic trees. Molecular Biology and Evolution, 4: 406-425.

Schurr T.G. (2004) An anthropological genetic view of the peopling of the New World. In: Barton C.M., Clark G.A., Yesner D.R., and Pearson G.A. (eds.), The Settlement of the American Continents: A Multidisciplinary Approach to Human Biogeography. The University of Arizona Press, Tucson, pp. 1127.

Schurr T.G. (2006) Tracking genes through time and space: changing perspectives on New World origins. In: Bonnichsen R., Lepper T., Stanford D., and Waters M.R. (eds.), Paleoamerican Origins: Beyond Clovis. Texas A\&M University Press, College Station, pp. 221-242.

Schurr T.G., Ballinger S.W., Gan Y.Y., Hodge J.A., Merriwether D.A., Lawrence D.N., Knowler W.C., Weiss K.M., and Wallace D.C. (1990) Amerindian mitochondrial DNAs have rare Asian mutations at high frequencies suggesting a limited number of founders. American Journal of Human Genetics, 46: $613-623$

Seguchi N. (2000) Secular change in the Japanese occlusion: the frequency of the overbite and its association with food preparation techniques and eating habits. Ph.D. dissertation. Anthropology, University of Michigan, Ann Abor.

Seguchi N. (2004) Craniometric view from the Late Pleistocene and Early Holocene of East Asia: the Zhoukoudian Upper Cave and Minatogawa. American Journal of Physical Anthropology, 123, Supplement 38: 178.

Seguchi N., Nelson A.R., Austin S., and Brace C.L. (2005) Early South Americans in craniofacial metric perspective: Lagoa Santa. American Journal of Physical Anthropology, 126, Supplement 39: 187

Seguchi N., Umeda, H., Nelson A.R., and Brace C.L. (2006) Do early South Americans show biological similarity to Australians? Lagoa Santa in odontometric and craniometric perspective. American Journal of Physical Anthropology, 129, Supplement 42: 162

Sjøvold T. (1984) A report on the heritability of some cranial measurements and non-metric traits. In: Van Vark G.N. and Howells W.W. (eds.), Multivariate Statistical Methods in Physical Anthropology Dordrecht: D. Reidel Publishing Co., Boston, pp. 223-246.

Smith D.G., Malhi R.S., Eshleman J.A., Kaestle F.A., and Kemp B.M. (2006) Mitochondorial DNA haplosamples of Paleoamericans in North America. In: Bonnichsen R., Lepper T., Stanford D., and Waters M.R. (eds.), Paleoamerican Origins: Beyond Clovis. Texas A\&M University Press, College Station, pp. 243-254.
Sparks C.S. and Jantz R.J. (2002) A reassessment of human cranial plasticity: Boas revisited. Proceedings of the National Academy of Sciences of the United States of America, 99: 1463614639

Steadman D.W. (2001) Mississippians in motion? A population genetics analysis of interregional gene flow in west-central Illinois. American Journal of Physical Anthropology, 114: 61-73.

Steele D.G. and Powell J.F. (1992) The peopling of the Americas: the paleobiological evidence. Human Biology, 63: 301-336.

Steele D.G. and Powell J.F. (1998) Historical review of the skeletal evidence for the peopling of the Americas. Paper presented at the Annual Meeting of the Society for American Archaeology, March 13, 1998, Seattle, Washington.

Steele D.G. and Powell J.F. (1999) Peopling of the Americas: a historical and comparative perspective. In: Bonnichsen R. (ed.), Who Were the First Americans? Center for the Study of the First Americans, Oregon State University, Corvallis, pp. 97-126.

Steele D.G. and Powell J.F. (2002) Facing the past: a view of the North American human fossil record. In: Jabolonski N.G. (ed.), The First Americans: The Pleistocene Colonization of the New World. University of California Press, Berkeley, pp. 93-122.

Stojanowski C.M. (2004) Population history of Native groups in Pre- and Post-Contact Spanish Florida: Aggregation, gene flow, and genetic drift on the Southeastern U.S. Atlantic coast. American Journal of Physical Anthropology, 123: 316332.

Stojanowski C.M. (2005) Spanish colonial effects on Native American mating structure and genetic variability in northern and central Florida: Evidence from Apalachee and western Timucua. American Journal of Physical Anthropology, 128: $273-286$.

Suzuki H. (1963) Nihonjin no hone [Japanese skeletons]. Iwanami Shoten, Tokyo (in Japanese).

Suzuki H. (1969) Microevolutional changes in the Japanese population from the prehistoric age to the present-day. Journal of the Faculty of Science, University of Tokyo, Section 5, Anthropology, 3: 279-309.

Ubelaker D.H. (1992) Patterns of demographic change in the Americas. Human Boiology, 64: 361-379.

Van Vark G.N. and Dijkema J. (1988) Some notes on the origin of the Chinese people. Homo, 39: 143-148.

Van Vark G.N. and Schaafsma W. (1992) Advances in the quantitative analysis of skeletal morphology. In: Saunders S.R. and Katzenberg M.A. (eds.), Skeletal Biology of Past Peoples: Research Methods. Wiley Liss, New York, pp. 225-257.

Van Vark G.N., Kuizenga D., and Williams F.L. (2003) Kennewick and Luzia: lessons from the European Upper Paleolithic. American Journal of Physical Anthropology, 121: 181-184.

Verneau R. (1903) Les anciens Patagons. Contributions a l'Étude des races Précolombiennes de l'Amérique du Sud. Imprimerie de Monaco, Monaco.

Verneau R. (1924) Crânes d'Indiens de la Colombie. L'élément papoua en Amérique. L'Anthropologie, 34: 353-386.

Williams-Blangero S. and Blangero J. (1989) Anthropometric variation and the genetic structure of the Jirels of Nepal. Human Biology, 61: 1-12.

Wolpoff M.H. (1994) Review of 'The Evolution and Dispersal of Modern Humans in Asia' (Akazawa T., Aoki K., and Kimura T. eds.). American Anthropologist, 96: 184-187.

Wolpoff M.H. (1995) Right for the wrong reasons. Journal of Human Evolution, 29: 185-188.

Woo T.L. and Morant G.M. (1934) A biometric study of the 'flatness' of the facial skeleton in man. Biometrika, 26: 196260.

Wright R.V.S. (1995) The Zhoukoudian Upper Cave skull 101 and multiregionalism. Journal of Human Evolution, 29: 181-183. 